\title{
Integration of multivariate statistics and water quality indices to evaluate groundwater quality and its suitability in middle Gangetic floodplain, Bihar
}

\author{
Ajay Govind Bhatt ${ }^{1}$. Anand Kumar ${ }^{2}$ - Priya Ranjan Trivedi ${ }^{1}$
}

Received: 4 December 2020 / Accepted: 17 February 2021 / Published online: 6 March 2021

(c) The Author(s) 2021 OPEN

\begin{abstract}
This study is conducted along the middle Gangetic floodplain, to investigate the hydrogeochemical characteristics and suitability of groundwater for irrigation and human consumptions. Altogether 65 groundwater samples were collected and analyzed for major ions and water quality parameters. $\mathrm{pH}$ of all the samples except 1 is found $>7$, which suggests alkaline aquifer condition. Groundwater samples predominately belong to $\mathrm{Ca}-\mathrm{Mg}-\mathrm{HCO}_{3}$ water type followed by $\mathrm{Na}-$ $\mathrm{HCO}_{3}, \mathrm{Mg}-\mathrm{HCO}_{3}$ and $\mathrm{Mg}-\mathrm{SO}_{4}$ water types. Hierarchical cluster analysis (HCA) combines groundwater into two distinct groups, Group 1 is found as less mineralized as the average EC value is found $625.3 \mu \mathrm{S} / \mathrm{cm}$, while it is found $1375 \mu \mathrm{S} /$ $\mathrm{cm}$ for Group 2. The results of correlation analysis and PCA suggest influence of natural and anthropogenic activities on groundwater. PCA extracts four major PCs which describes $71.7 \%$ of total variance. PC1 indicates influence of both lithogenic and anthropogenic activities on groundwater quality. PC2 and PC3 infer natural factors, and PC4 suggests influence of anthropogenic activities on groundwater. Exceeding concentration of $\mathrm{F}^{-}$, Fe and $\mathrm{Mn}$ above WHO guidelines are found as major public health concern. WQI of all except 4 groundwater samples suggests excellent to good water quality; however, $23 \%$ of the samples are not suitable based on WPI values. Irrigation indices suggest that groundwater is mostly suitable for irrigation; however, $10.7 \%, 12.3 \%$ and $3 \%$ samples for RSBC, MAR and KR, respectively, exceed the recommended limits and are unsuitable for irrigation. A proper management strategy and quality assurance is recommended before groundwater consumption and use in the study area.
\end{abstract}

Keywords Groundwater quality · Alluvial floodplain · Hydrogeochemical process · Water quality indices · Irrigation water quality. GIS

\section{Introduction}

Groundwater is the largest and most reliable source of safe water supply across the globe, and it is widely used for human consumption, agriculture and industries activities. According to estimates approximately, one-third of the population across the globe rely on groundwater for drinking [1-3]; however, out of total groundwater use 65\% is used for drinking, $20 \%$ is used for irrigation and livestock, and rest $15 \%$ is used for mining and industrial activities $[3,4]$. In recent past, rapid industrialization, unplanned urbanization, waste discharge and other demographic changes have increased the pressure on groundwater resources, both in terms of its quantity and quality [5-7].

Supplementary Information The online version contains supplementary material available at https://doi.org/10.1007/s42452-021-04394 $-\mathrm{x}$.

$\triangle$ Anand Kumar, anandeverst@gmail.com |'Indira Gandhi Technological and Medical Sciences University,

Zero, Arunachal Pradesh 791120, India. ${ }^{2}$ Dept. of Energy and Environment, TERI School of Advanced Studies, New Delhi 110070, India. 
Groundwater quality is mostly govern by the natural process as it largely depends on regional geology and aquifer mineral compositions. During groundwater development when water moves through its flow path it interacts with aquifer minerals through various hydrogeochemical processes such as oxidation-reduction, weathering, precipitation, dissolution, ion exchange [6-10]. In addition, natural factors including residence time, rock-water interaction, soil gas interaction, zone of recharge-discharge, intermixing of water, climatic condition and surface topography also play an important role in determining the ionic species in groundwater [9-11]. Apart from these natural factors, anthropogenic activities such as over-withdrawal of groundwater, unplanned land use land cover, leaching of fertilizers, herbicides, pesticides, agricultural runoff and industrial discharge may also alter the groundwater composition [12-14]. Groundwater is renewable in terms of quantity as it is replenished annually by precipitation; however, the change in climatic condition along with the overexploitation of groundwater has altered the natural cycle resulting decline in groundwater table [15].

The optimal quality and quantity of groundwater is most important in determining its suitability for various human use. However, at the same time assurance of groundwater quality is a major challenge and it needs combined efforts $[16,17]$. To understand the quality of groundwater, methods such as chemometric analysis, stable isotopes, hydrogeochemical modeling, trace elements, redox indicator and mineral phase equilibrium, geochemical modeling have been extensively used across the globe $[6,9,11,13]$. However, to summarize the overall water quality from a large number of water quality parameters water quality index (WQI) was developed [18]. WQI is a numeric method which integrates a large number of parameters in single dimensionless number by selecting and weighting the water quality parameters and aggregating them on basis of their significance $[16,17$, 19]. Although WQI is widely used as an effective indicator of overall groundwater quality, it has been also modified as drinking water quality index (DWQI), water pollution index (WPI), comprehensive pollution index (CPI), irrigation water quality index (IWQI), entropy weighted water quality index (EWQI), pollution index of groundwater (PIG), composite water quality index (CWQI) and aquatic life water index (ALWI) [16, 17, 19-25]. In addition to drinking water quality indices, irrigation water quality indices, i.e., hardness, sodium adsorption ratio (SAR), residual sodium carbonate (RSC), residual sodium bicarbonate (RSB), permeability index $(\mathrm{PI})$, magnesium hazard $(\mathrm{MH})$, sodium percentage ( $\mathrm{Na} \%)$, potential salinity (PS) and Kelly's ratio (KR) are used to understand the irrigation water quality [3, 26-28]. The results of these indices have been integrated with geographic information system (GIS) to represent spatial distribution and prioritizing the areas, which needs proper attention for groundwater management [19, 22, $25,28]$.

Concentration of ions present in groundwater used for drinking and irrigation is the key source for micronutrients and minerals for human and plants; however, the exceeding concentration of these ions may have negative implications $[6,10,29,30]$. The severity of health implications due to contaminated groundwater varies in exposed individuals; factors such as exposed duration, exposure frequency, dose of the contaminants, food habit and nutrient intake may determine the extent of health risk $[6,31]$. Similarly, the excess of ions present in irrigation water may reduce the soil fertility by increasing the risk of salinity, infiltration and permeability threat, micronutrient toxicity, ion/trace elements toxicity and other crops-specific effects [32]. It may also affect the morphology and physiology of the plants and reduce the overall crop production. In addition, bioaccumulation of metals and metalloids in crops has potential to inter into food chain [33,34]. The quality of water used for industrial activities is also important as inappropriate water in industrial operation can cause corrosion or scaling on material/container surface resulting an increase in the maintenance and operational costs [35].

The study area is a part of middle Gangetic floodplain, where groundwater is extensively used for drinking and agriculture activities. Decline in groundwater table is observed along the Indo-Gangetic basin [15]; however, the presence of both inorganic and organic contaminants has raised the concern a scale higher [36-39]. The rural population residing in the study area largely relies on groundwater for their drinking and agricultural purpose, however, without any quality assurance. With these backgrounds the present study is intend to assess the hydrogeochemical evolution of groundwater and its suitability for drinking and irrigation use in Bihar. Along with the ionic ratio, chemometric methods are used to understand the hydrogeochemical process responsible for ionic evolution. The water quality indices are used to assess the suitability for drinking and irrigation. Later the outcomes are represented with GIS map to understand the spatial pattern to prioritize efficient management strategies.

\section{Material and methods}

\subsection{Study area}

This study is conducted in Arwal and Jehanabad districts of Bihar (Fig. 1), which lies in the middle Gangetic floodplain, under Son and Punpun sub-basins. River Son and Punpun are the perennial stream flowing through the study area; however, the other seasonal channels such as 
Fig. 1 Study area map with spatial distribution of collected samples and soil type

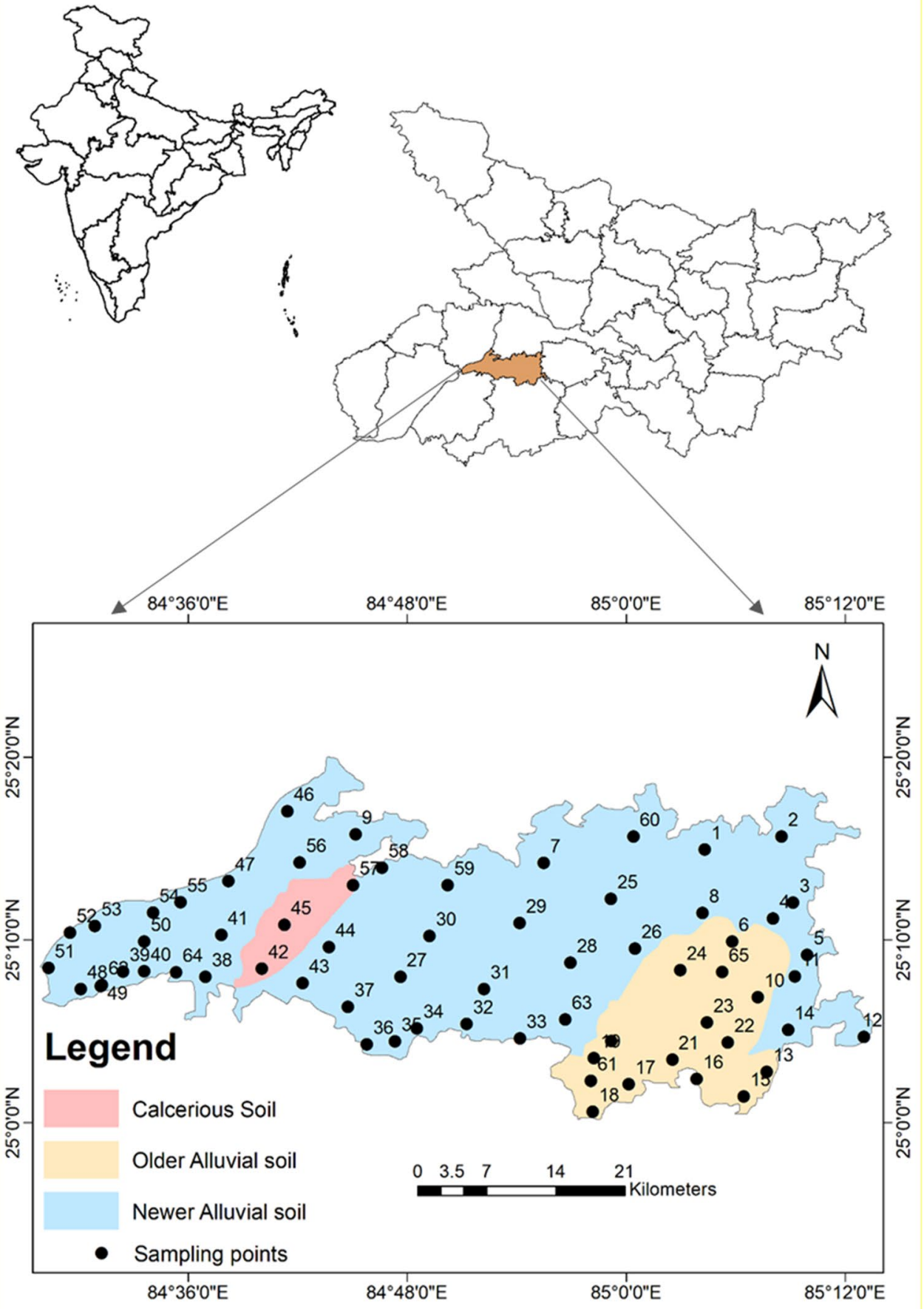

Dardha, Phalgu, Jamuna, Morhar flows during the monsoon remain dry in other seasons. The study area has a gentle slope toward north, and these rivers follow the surface topography and meet into the main channel of river Ganga. River Son acts as a boundary at the eastern part of the study area, and the groundwater from the opposite bank is reported with high arsenic (As) exceeding WHO guidelines [37, 40]; however, no such detailed studies have been conducted to understand the groundwater quality in the study region. The study area has extreme climate as the temperature is recorded up to $45^{\circ} \mathrm{C}$ during summer and it goes down to $3-4{ }^{\circ} \mathrm{C}$ winters. The average annual rainfall is $1052 \mathrm{~mm}$ out of which $60 \%$ of the rain occurs in the monsoon season, i.e., July and August months. As the study area is the alluvial floodplain with dominance of loam and small proportion of sand and clay, the surface soil is highly fertile and it has a high percentage of calcium and nitrogen. The area is under extensive agriculture in both Rabi and Kharif seasons. Along with paddy, maize, wheat, cane, potato, pulses and vegetables are the major 
crops grown in the study area. Chemical fertilizers, i.e., urea $\left(\mathrm{CH}_{4} \mathrm{~N}_{2} \mathrm{O}\right)$, phosphatic fertilizer $\left(\mathrm{P}_{2} \mathrm{O}_{5}\right)$ and potash $\left(\mathrm{K}_{2} \mathrm{O}\right)$, are frequently used to improve the crop yield. Groundwater is extensively used for domestic and irrigation purpose, however, development of groundwater resource is found positive, and there is no long-term decline in groundwater table [38].

The underlined geology of the study area has vast tract of Indio Gangetic Quaternary aged alluvium, deposited by the rivers (Fig. 2). The quaternary sequence is further divided into Holocene, i.e., newer alluvium and Pleistocene, i.e., older alluvium $[39,40]$. The central and western part of the study area has dominance of Holocene sediment which are organically rich entrenched channels and floodplains, while the Pleistocene older alluvium are found mostly in the eastern part of the study area (Fig. 2) and it has yellow-brown color with profuse calcareous and ferruginous concretions [41]. Presence of inselbergs is also reported in the south eastern part, among which Barabar hills are the most prominent with maximum height $312 \mathrm{~m}$ from mean sea level [38]. Aquifers in this region are composed of gravel, sand and clay among which course to medium sand and gravels are the major repository for groundwater. Majority of the area has dominance of alluvial formation; however, in some patches clay are prominent [38]. Alternate layers of clay, sand, sandy clay and silt are observed up to $135 \mathrm{~m}$; however, the basement varies from 120 to $150 \mathrm{~m}$ below land surface $[38,41]$. The expulsion from the aquifers is very good, and the hourly discharge varies from $20 \mathrm{~m}^{3} / \mathrm{hr}$ to $50 \mathrm{~m}^{3} / \mathrm{hr}$ in shallow and deep aquifers, respectively. The depth of groundwater varies from 2 to $5 \mathrm{~m}$ as in premonsoon it is found $5-10 \mathrm{~m}$ below ground level; however, in postmonsoon it is found 2-5 $\mathrm{m}$ below the ground [38].

\subsection{Collection of samples and field analysis}

To investigate the groundwater quality in the study area, a total of 65 samples were collected from March 15 to 18 , 2019. The wells were expelled for 5-6 min to eliminate the impacts of iron cast pipes on groundwater quality. The physical parameters, i.e., $\mathrm{pH}$, electrical conductivity $(E C)$ and oxidation reduction potential (ORP), were tested onsite, and in addition to that, information regarding the depth and age of the wells was gathered from the well owner. The handheld pH tester (HANNA (HI98107P) and DiST waterproof EC tester HANNA (HI98303) were calibrated every day before use with the reference solution of $84 \mu \mathrm{S} / \mathrm{cm}, 1413 \mu \mathrm{S} / \mathrm{cm}$ and $12.8 \mathrm{mS} / \mathrm{cm}$ for EC; however, $\mathrm{pH}$ probe was calibrated with standard reference solution of 4.0, 7.0 and 10.0. The readings of the probes were stable, and no systematic or temporal drift in the reading was observed. After measurement of field parameters two set of samples were collected in prewashed and dried
Fig. 2 Geology map of study area

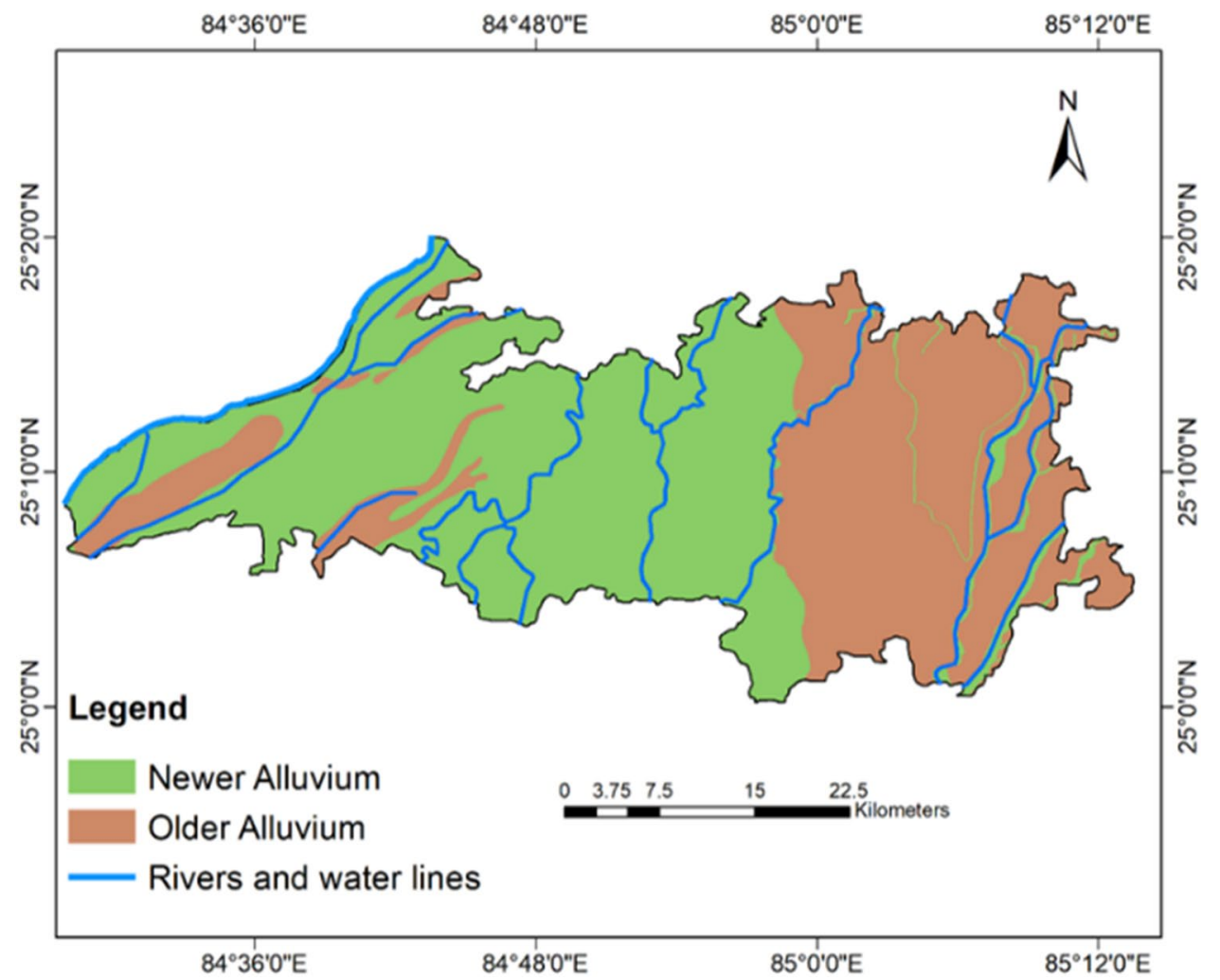


high-density polyethylene (HDPE) bottles. One set of sample collected for cation analysis was acidified onsite using the analytical grade $6 \mathrm{~N} \mathrm{HNO}_{3}$ (Ultrapure Merck); however, the other for anions analysis was not acidified. Both set of samples were filled up to the top to avoid any headspace and kept in ice box to avoid direct sunlight. After collection, samples were brought to the laboratory and analyzed using the standard protocols, within 10 days of sampling.

\subsection{Laboratory analysis of groundwater}

An acidified groundwater samples were used to analyze major cations, i.e., sodium $\left(\mathrm{Na}^{+}\right)$, calcium $\left(\mathrm{Ca}^{2+}\right)$, magnesium $\left(\mathrm{Mg}^{2+}\right)$, potassium $\left(\mathrm{K}^{+}\right)$along with arsenic $(\mathrm{As})$, iron $(\mathrm{Fe})$ and manganese $(\mathrm{Mn})$ using inductively coupled plasma (OES 700 series). The reproducibility was found with in order of $5 \%$ for all the cations. Un-acidified sample was used to estimate the anionic species, i.e., bicarbonate $\left(\mathrm{HCO}_{3}{ }^{-}\right)$, chloride $\left(\mathrm{Cl}^{-}\right)$, nitrate $\left(\mathrm{NO}_{3}{ }^{-}\right)$and sulfate $\left(\mathrm{SO}_{4}{ }^{2-}\right)$ in groundwater. Titrimetric method was used to estimate the concentration of $\mathrm{HCO}_{3}{ }^{-}$and $\mathrm{Cl}^{-}$in groundwater as prescribed in APHA, 2008. $\mathrm{NO}_{3}{ }^{-}$concentration was measured using the screening method on UV-Visible spectrophotometer (Labman). As prescribed groundwater samples were treated with $1 \mathrm{~N} \mathrm{HCl}$ to avoid any interference due to hydroxides/carbonates present in the sample. Turbidimetric method was used for $\mathrm{SO}_{4}{ }^{2-}$, and the absorbance was recorded at $420 \mathrm{~nm}$ wavelength using spectrophotometer [42]. The detection limits of the instruments for each of the groundwater quality parameter are provided in supplementary Table 1. For quality assurance, all the chemicals were of Merck analytical grade and the replicate was analyzed after ever 5 samples. The sample replicates were found within $5 \%$ for all the water quality parameters.

The normalized charged balance index (NCBI) was calculated using the following equation, where $T z^{-}$is the total sum of anions (in epm) and $T z^{+}$is total sum of cations (in epm) $[7,9,10,22,31]$.

$\mathrm{WQI}=\sum_{i=1}^{n} W i \times Q i$

\subsection{Multivariate analysis}

Statistical analysis is performed to identify the hidden dimensions among the groundwater variables which cannot be interpreted using direct analysis. Hierarchical cluster analysis (HCA) of groundwater quality parameters is performed to cluster statistically distinct hydrochemical parameters [9]. HCA is the unsupervised pattern detection method which groups the variables based on their similarity. HCA is the most common approach
Table 1 List of groundwater quality parameters, with relative assigned weights, used in the computation of WQI

\begin{tabular}{llll}
\hline Parameter & $\begin{array}{l}\text { WHO Guideline } \\
2011\end{array}$ & Weight & Relative weight \\
\hline $\mathrm{PH}$ & 6.5 & 3 & 0.055556 \\
$\mathrm{TDS}$ & 500 & 5 & 0.092593 \\
$\mathrm{Ca}^{2+}$ & 100 & 3 & 0.055556 \\
$\mathrm{Mg}^{2+}$ & 50 & 4 & 0.074074 \\
$\mathrm{Na}^{+}$ & 200 & 4 & 0.074074 \\
$\mathrm{~K}^{+}$ & 20 & 2 & 0.037037 \\
$\mathrm{HCO}_{3}{ }^{-}$ & 125 & 1 & 0.018519 \\
$\mathrm{Cl}^{-}$ & 250 & 5 & 0.092593 \\
$\mathrm{SO}_{4}{ }^{2-}$ & 200 & 4 & 0.074074 \\
$\mathrm{NO}_{3}{ }^{-}$ & 50 & 5 & 0.092593 \\
$\mathrm{~F}^{-}$ & 1.5 & 5 & 0.092593 \\
$\mathrm{As}$ & 10 & 5 & 0.092593 \\
$\mathrm{Fe}$ & 0.3 & 4 & 0.074074 \\
$\mathrm{Mn}^{T}$ & 0.5 & 4 & 0.074074 \\
\hline
\end{tabular}

World Health Organization (WHO 2011). Guideline for drinking water quality

which represent the intuitive similarity between the variables by dendrogram, a visual summary of groups with dimension reduction in original dataset. Z-score transformation was applied to standardize the original data and avoid any misclassification due to the wide range in the data dimension [43]. Q-mode cluster analysis was performed using the wards linkage method with Euclidean distance, to understand the spatial linkages between the groundwater qualities parameters analyzed in this study [9].

Principle component analysis (PCA) was performed using varimax rotation method combined with Kaiser normalization to reduce the volume of the large-scale dataset with minimum loss of information $[9,45]$. The values of chemical variables of groundwater have been used for PCA using SPSS software. The values were autoscaled with mean 0 and variance 1 . The Bartlett's sphericity test of normalized data has $\chi^{2}(\mathrm{cal})=1285$ found more than the $\chi^{2}$ (crit) $=86$ (degree of freedom 136 , significance level 0.05 and $p$ value $<0.0001$ ) suggests that PCA can be applied successfully. The principle components (PCs) having eigen values $>1$ were considered for data interpretation $[9,44]$. The loading of each PCs, which is the uncorrelated variable obtained by multiplying the original correlated variables, explains the comparative influence of chemical species on groundwater $[7,9]$. The loading of variables $>0.75$ is termed as strong, $0.75-0.50$ as moderate and $0.05-0.30$ as weak loading. 


\subsection{Geostatistical tools}

The spatial location of the groundwater samples has been used to produce the spatial distribution maps of water quality parameters and indices. The inverse distance weighted (IDW) method of spatial interpolation is widely used to generate surface map in groundwater-related studies. The IDW method calculates the moving average of the variable as it relies that the local factors have a significant influence; however, it reduces with increasing distance [10]. The values of water quality parameters and respective indices are interpolated using IDW algorithm in spatial analyst module of Arc GIS 10.3.1. The geological map of the study area was obtained from the Geological Survey of India (GSI) and digitized using Arc GIS.

\subsection{Drinking water quality indices}

\subsubsection{Water quality index (WQI)}

WQI is an effective decision-making tool for management of water resources as it provides a holistic overview of water quality and its suitability for various human use [46]. WQI is a numeric method to reduce large number of water quality variables in most scientific and instructive manner and their aggregate impacts on water quality $[18,35]$. This is widely used by decision makers across the globe to provide significant information for sustainable water resources management $[19,22,24,27,35,46]$.

Calculation of WQI has four major steps, (a) analyst of water quality parameters, (b) transformation in dimensionless number, (c) weightages assign based on their significance and (d) aggregation of quality rating on the basis of the final WQI values $[22,24,25,46]$. The weightages are assigned on a scale of $1-5$, based on the threat to water quality parameters on public health. The maximum weight 5 is assigned to TDS, $\mathrm{F}^{-}, \mathrm{Cl}^{-}, \mathrm{NO}_{3}{ }^{-}$based on their significant health implication; however, the lowest weight, i.e., 1 is assigned to $\mathrm{HCO}_{3}{ }^{-}$. The relative weight is calculated using Eq. 3.

WQI is calculated using Eq. (2)

$\mathrm{WQI}=\sum_{i=1}^{n} W i \times Q i$

where $Q i$ is the quality rating, and $W i$ is relative weight of each parameters, which is calculated by Eq. (3)

$W i=\frac{w i}{\sum_{i=1}^{n} w i}$
$W i$ is relative weight, wi is weight of each parameter, and $n$ is the total number of parameters. $Q i$ is calculated using Eq. (4)

$Q i=100 \times \frac{C i}{S i}$

where $\mathrm{C} i=$ Concentration of the water quality parameters $(\mathrm{mg} / \mathrm{l})$, and $\mathrm{Si}=$ Prescribed standards. For calculation of $\mathrm{Si}$, WHO, 2011 drinking water standards are used. Depending on the values of each parameter weightages on a scale of 1 to 5 have been assigned; further, the relative weight is calculated (Table 1).

\subsubsection{Water pollution index (WPI)}

The measured groundwater quality parameters are used to estimate the pollution load, based on their prescribed limits by world health organization [47]. WPI in an integrated approach and can be applied on wide range of data set as it converts all the input parameters to a single value which represents the entire pollution load and water quality. In this study all together 15 groundwater variables are used to calculate WPI; however, it provides flexibility to add more numbers of water quality parameters [48].

The WPI is calculated using following Eq. (5)

$\mathrm{WPI}=\frac{1}{n} \sum_{i=1}^{\mathrm{n}} P L i$

where $\mathrm{n}$ is the number of variables and $P L i$ is the pollution load which is calculated using Eq. (6)

$\mathrm{PLi}=1+\frac{C i-S i}{S i}$

where $\mathrm{Ci}$ is the concentration of $i$ th parameter, and $\mathrm{Si}$ is the recommended standard which is taken from the WHO in this study (Table 1). In case of $\mathrm{pH}$ the recommendation limit is in range (6.5-8.5) so if the $\mathrm{pH}$ is $<7$, then Eq. 6.1 is recommended.

$P L i=\frac{C i-7}{S i a-7}$

where $\mathrm{Si}_{a}$ is the minimum acceptable $\mathrm{pH}$, i.e., 6.5. However if the $\mathrm{pH}$ is $>7$ in that case $\mathrm{Si}_{b}$ is recommended which is the maximum recommended value, i.e., 8.5 and the modified equation would be as Eq. 6.2.

$P L i=\frac{C i-7}{S i b-7}$

In this study all the samples have $\mathrm{pH}>7$, except 1 for which Eq. 6.1 is used. 


\subsubsection{Irrigation water quality indices}

The ionic concentration of irrigation water reveals its makeup, and it also provides an understanding about the possible impacts on soil quality and plant growth [46]. The qualitative assessment of water is evaluated using the several indices such as sodium absorption ratio (SAR), sodium percentage ( $\mathrm{Na} \%)$, magnesium hardness, Kelly's ratio (KR), residual sodium bicarbonate concentration (RSBC), magnesium absorption ratio (MAR), permeability index (PI) and residual sodium carbonate (RSC). These indices are estimated to assess the suitability of water for irrigation and other activities $[46,49,50]$. The details of these indices and the formulas used for computation of irrigation water quality parameters are provided in Table 2.

Table 2 Irrigation water quality parameters and formula used for their computation

\begin{tabular}{ll}
\hline Parameters & Formula \\
\hline Sodium adsorption ratio (SAR) & $\frac{\mathrm{Na}}{\sqrt{(\mathrm{Ca}+\mathrm{Mg})}}$ \\
Soluble sodium percent (SSP) & $\frac{(\mathrm{Na+K}) \times 100}{\mathrm{Ca}+\mathrm{Mg}+\mathrm{Na}+\mathrm{K}}$ \\
Residual sodium carbonate index (RSC) & $\left(\mathrm{CO}_{3}+\mathrm{HCO}\right)-(\mathrm{Ca}+\mathrm{Mg})$ \\
Residual sodium bicarbonate index (RSBC) & $\left(\mathrm{HCO}_{3}-\mathrm{Ca}\right)$ \\
Permeability index (PI) & $\frac{\mathrm{Na}+\sqrt{\mathrm{HCO} 3}}{\mathrm{Ca}+\mathrm{Mg}+\mathrm{Na}} \times 100$ \\
Magnesium adsorption ratio (MAR) & $\frac{\mathrm{Mg} \times 100}{\mathrm{Ca}+\mathrm{Mg}}$ \\
Kelly's ratio & $\frac{\mathrm{Na}}{\mathrm{Ca}+\mathrm{Mg}}$ \\
Sodium to calcium activity ratio (SCAR): & $\frac{\mathrm{Na}}{\mathrm{Ca}}$ \\
\% Sodium & $\frac{\mathrm{Na}+\mathrm{K}}{\mathrm{Ca}+\mathrm{Mg}+\mathrm{Na}+\mathrm{K}} \times 100$ \\
\hline
\end{tabular}

\section{Results and discussion}

\subsection{Hydrogeochemistry}

The statistical summary of groundwater parameters is helpful in identifying their evolution and variation. Table 3 provides the statistical summary of groundwater quality variables with respect to their recommended values for drinking and irrigation use. The groundwater of study area is slightly alkaline as all the groundwater samples except 1 have $\mathrm{pH}>7$. The $\mathrm{pH}$ values vary from 6.9 to 8.3 with an average of 7.6. The total alkalinity of groundwater varies from 2 to $14.6 \mathrm{mg} / \mathrm{L}$ with an average of $6.7 \mathrm{mg} / \mathrm{L}$. High interaction of rainwater with atmospheric $\mathrm{CO}_{2}$ and the air present in the soil imparts alkalinity in groundwater aquifers [51]. Total dissolved solid (TDS) is measures of dissolved solids concentration and an important indicator of palatability, and it ranges from 149 to $1609 \mathrm{mg} / \mathrm{L}$ with an average of $560.8 \mathrm{mg} / \mathrm{L}$. Based on the classification by Davis and Dewiest 11 out of 65 collected samples fall under fresh water, 50 samples are under marginal water type, and remaining 4 water samples fall under brackish water type [52]. BIS has not set any standard for EC in drinking water, however, according to the WHO recommends EC up to $1500 \mu \mathrm{S} / \mathrm{cm}$ [47]. Four samples in the study are high EC exceeding WHO guidelines (Table 3). The high concentration of EC and TDS might be attributed due to soil mineralization, resulting in increase in ionic activity in groundwater aquifer $[9,10]$. The spatial variation in groundwater quality parameters is observed which could be the result of dissolution and saturation of ions [44].

Table 3 List of groundwater quality parameters, with relative assigned weights, used in the computation of WQI

\begin{tabular}{|c|c|c|c|c|c|c|c|c|}
\hline Variable & Min & Max & Average & Std. dev & $\begin{array}{l}\text { WHO guide- } \\
\text { line (2011) }\end{array}$ & $\begin{array}{l}\text { Samples exceeding } \\
\text { WHO guideline (\%) }\end{array}$ & $\begin{array}{l}\text { Irrigation water } \\
\text { guideline BIS } 2012\end{array}$ & $\begin{array}{l}\text { Samples exceeding } \\
\text { BIS guideline (\%) }\end{array}$ \\
\hline $\mathrm{pH}$ & 6.9 & 8.3 & 7.6 & 0.3 & $6.5-8.5$ & - & 8.5 & - \\
\hline $\mathrm{EC}$ & 198 & 2370 & 809.9 & 428.9 & 1500 & 6.2 & - & - \\
\hline $\mathrm{Cl}^{-}$ & 3.8 & 289.3 & 55.5 & 61.7 & 250 & 1.5 & 1000 & - \\
\hline $\mathrm{HCO}_{3}^{-}$ & 80 & 584 & 284.6 & 84.4 & 300 & 32.3 & - & - \\
\hline $\mathrm{SO}_{4}^{2-}$ & 1.7 & 74.2 & 20.4 & 16.8 & 250 & - & 400 & - \\
\hline $\mathrm{NO}_{3}^{-}$ & 0.1 & 18.7 & 3.8 & 4 & 50 & - & 45 & - \\
\hline $\mathrm{F}^{-}$ & $\mathrm{BDL}$ & 2.1 & 0.8 & 0.5 & 1.5 & 15.4 & - & \\
\hline $\mathrm{Na}^{+}$ & 14 & 250 & 60.5 & 48.6 & 200 & 3.1 & 400 & - \\
\hline $\mathrm{K}^{+}$ & 1 & 65 & 5.5 & 11.3 & 30 & 3.1 & 12 & 9.2 \\
\hline $\mathrm{Mg}^{2+}$ & 4.8 & 102.1 & 28 & 16.6 & 150 & - & 100 & 1.5 \\
\hline $\mathrm{Ca}^{2+}$ & 20 & 160.3 & 74.4 & 34 & 200 & - & 200 & - \\
\hline $\mathrm{Fe}$ & $\mathrm{BDL}$ & 4.6 & 0.57 & 0.73 & 0.3 & 52.3 & - & - \\
\hline As & $\mathrm{BDL}$ & 9 & 1.6 & 2.72 & 10 & - & - & - \\
\hline $\mathrm{Mn}$ & $\mathrm{BDL}$ & 0.2 & 0.05 & 0.05 & 0.4 & - & - & - \\
\hline TDS & 149 & 1609 & 560.8 & 287.2 & 1000 & - & 2000 & - \\
\hline
\end{tabular}


Oxidation-reduction potential an indicator for aquifer environment indicates the aquifers are oxic as the values range from 2.4 to $265 \mathrm{mg} / \mathrm{L}$ (Table 3 ).

Among the cations $\mathrm{Ca}^{2+}$ is found as most dominant followed by $\mathrm{Na}^{+}>\mathrm{Mg}^{2+}>\mathrm{K}^{+}$, and its concentration varies from 20 to $160 \mathrm{mg} / \mathrm{L}$ with an average values of $74.4 \mathrm{mg} / \mathrm{L}$. $\mathrm{Na}^{+}$varies from 14 to $250 \mathrm{mg} / \mathrm{L}$ with an average of $60.5 \mathrm{mg} / \mathrm{L}$. The concentration of $\mathrm{Mg}^{2+}$ and $\mathrm{K}^{+}$ranges from 4.8 to $102 \mathrm{mg} / \mathrm{L}$ and 1.0 to $65 \mathrm{mg} / \mathrm{L}$ with an average of $28 \mathrm{mg} / \mathrm{L}$ and $11.3 \mathrm{mg} / \mathrm{L}$, respectively. The concentration of cations in groundwater is mostly governed by the interaction between groundwater and aquifer minerals through various geochemical processes such as weathering minerals, ion exchange, dissolution and precipitation $[9,44]$. Based on the WHO-recommended values all the cations fall under portable water quality except $3.1 \%$ of the samples which exceeds the recommended limit for $\mathrm{Na}^{+}$and $\mathrm{K}^{+}$, respectively. The concentration of As in groundwater varies from BDL to $9.0 \mu \mathrm{g} / \mathrm{L}$ with an average of $1.6 \mu \mathrm{g} / \mathrm{L}$, and all the samples have As below WHO guidelines. However, the concentration of $\mathrm{Fe}$ and $\mathrm{Mn}$ in $24.6 \%$ and $52.3 \%$ of collected samples exceeds the WHO guidelines for drinking (Table 3). The study area is a part of middle Gangetic flood plain where As in groundwater is major concern for drinking water supply and public health. However, in the present study, we have not found any high As sample exceeding WHO guideline.

The average anions concentration is found as $\mathrm{HCO}_{3}{ }^{-}>\mathrm{Cl}^{-}>\mathrm{SO}_{4}{ }^{2-}>\mathrm{NO}_{3}{ }^{-}$, and the concentration of $\mathrm{HCO}_{3}{ }^{-}$varies from 80 to $584 \mathrm{mg} / \mathrm{L}$ with an average of $284.6 \mathrm{mg} / \mathrm{L}$. High concentration of $\mathrm{Ca}^{2+}, \mathrm{Na}^{+}$along with $\mathrm{HCO}_{3}{ }^{-}$determines the hardness of groundwater. In total, $32.3 \%$ of groundwater samples has high $\mathrm{HCO}_{3}{ }^{-}$. $\mathrm{HCO}_{3}{ }^{-}$concentration in groundwater is mainly attributed due to the water soil interactions, root respiration and degradation of organic matters [6]. Concentration of $\mathrm{Cl}^{-}$ions ranges from 3.8 to $289.3 \mathrm{mg} / \mathrm{L}$ with an average of $55.5 \mathrm{mg} / \mathrm{L}$. Climatic condition such as high evaporation attributes $\mathrm{Cl}^{-}$ions in groundwater; however, dissolution of halite minerals is also considered as the source of $\mathrm{Cl}^{-}$in groundwater [45]. The average values of $\mathrm{SO}_{4}{ }^{2-}$ and $\mathrm{NO}_{3}{ }^{-}$are found $27.9 \mathrm{mg} / \mathrm{L}$ and $3.7 \mathrm{mg} / \mathrm{L}$, respectively. The concentration of $\mathrm{SO}_{4}{ }^{2-}$ and $\mathrm{NO}_{3}{ }^{-}$in groundwater is attributed mainly due to anthropogenic activities such as leaching of fertilizers and agricultural runoff, municipal waste, leakages from the septic tank $[18,54]$. Study area is under extensive agriculture, and nitrogenous fertilizers are frequently used to improve the fertility in this region. Leaching of agricultural runoff might contribute $\mathrm{NO}_{3}{ }^{-}$in groundwater. Fluoride concentration varies from $B D L$ to $2.1 \mathrm{mg} / \mathrm{L}$ and $15.4 \%$, i.e., 10 out of 65 ; samples have high $\mathrm{F}^{-}$exceeding $\mathrm{WHO}$ guideline of $1.5 \mathrm{mg} / \mathrm{L}$. High $\mathrm{F}^{-}$may be attributed to the dissolution of fluoride-bearing minerals in the study area. The standard deviation of few groundwater quality parameters exceeds their average concentration which indicates that the geochemistry of study area is not homogenous $[9,10]$.

\subsection{Geochemical evolution of groundwater}

The chemical characteristics of groundwater depend on the interaction between the groundwater and subsurface rocks, minerals and sediment [9-13]. To understand the dominance of ionic species and hydrogeochemical facies Chadha diagram was plotted [55], which divides the groundwater into eight rectangular fields and each field corresponds to the major water facies and hardness (Fig. 3a). In Chadha diagram each number on the rectangular field provides the details of water facies as (1) represents alkaline earths exceeds alkali metals. (2) Alkali metals exceed alkaline earth elements. (3) Weak acidic anions concentration exceeds strong acid ions. (4) Strong acidic anions surpass weak acidic anions. (5) Alkaline earths and weak acid anionic species suppress alkali metals and strong acidic anions and represents $\mathrm{Ca}-\mathrm{Mg}-\mathrm{HCO}_{3}$ water type; (6) represents $\mathrm{Ca}-\mathrm{Mg}-\mathrm{Cl}$ water types where alkaline earths exceed alkali metals and strong acidic anionic species exceeds weak acidic anions; (7) represent the dominance of $\mathrm{Na}-\mathrm{Cl}$ and $\mathrm{Na}-\mathrm{SO}_{4}$ water type due to the excess of alkali metals over alkaline earths and strong acidic anion over weak acidic anions; (8) belongs to the $\mathrm{Na}-\mathrm{HCO}_{3}$ water types where alkali metals exceed alkaline earths and weak acidic anionic species exceeds over strong acidic species [55]. In this study, most of the groundwater samples fall in category 5, which represents $\mathrm{Ca}-\mathrm{Mg}-\mathrm{HCO}_{3}$ water type followed by $\mathrm{Na}-\mathrm{HCO}_{3}$ water type; however, a few water samples also correspond to $\mathrm{Mg}-\mathrm{HCO}_{3}$ and $\mathrm{Mg}-\mathrm{SO}_{4}$ water types (Fig. 4a).

To understand the hydrogeochemical processes responsible for the evolution of groundwater quality, the ionic species were plotted against the TDS concentration [56]. Gibbs diagram groups the samples in three major domains, i.e., rock water-dominant zone, evaporationdominant zone and precipitation-dominant zone [9, 23]. The groundwater quality is under the major influence of rock water dominance except for few samples which are influenced by the evaporation. The results of the Gibbs diagram indicate that the weathering of rocks and aquifer minerals is the controlling factor for evolution of ionic species in groundwater of the study region (Fig. 3b, c).

The ionic evolution of the groundwater is mainly controlled by the hydrogeochemical processes. The molar ratio of $\mathrm{Na}^{+}$vs $\mathrm{Cl}^{-}$is used to indicate the source of $\mathrm{Na}^{+}$ ions in groundwater, and the values close to the equiline suggest halite dissolution as major source; however, the values higher than 1 suggest the excess of $\mathrm{Na}^{+}$might be 
Fig. 3 a Chadha diagram representing ground water facies. b TDS versus $\mathrm{Cl} /\left(\mathrm{Cl}+\mathrm{HCO}_{3}\right)$.

c TSD versus $\left(\mathrm{Na}^{+}+\mathrm{K}^{+}\right) /($

$\left.\mathrm{Na}^{+}+\mathrm{K}^{+}+\mathrm{Ca}^{2+}\right)$. d Scatter plot

$\mathrm{Cl}^{-}$and $\mathrm{Na}^{+}$ions. e Scatter plot of $\mathrm{Na}^{+}$vs total cations (TC). $\mathbf{f}$

Scatter plot between CAII and

CAI II. g Scatter plot between

$\mathrm{Ca}+\mathrm{Mg}$ versus $\mathrm{SO}_{4}+\mathrm{HCO}_{3}$.

h Plot between TDS and

$\left(\mathrm{Cl}+\mathrm{NO}_{3}\right) / \mathrm{HCO}_{3}$
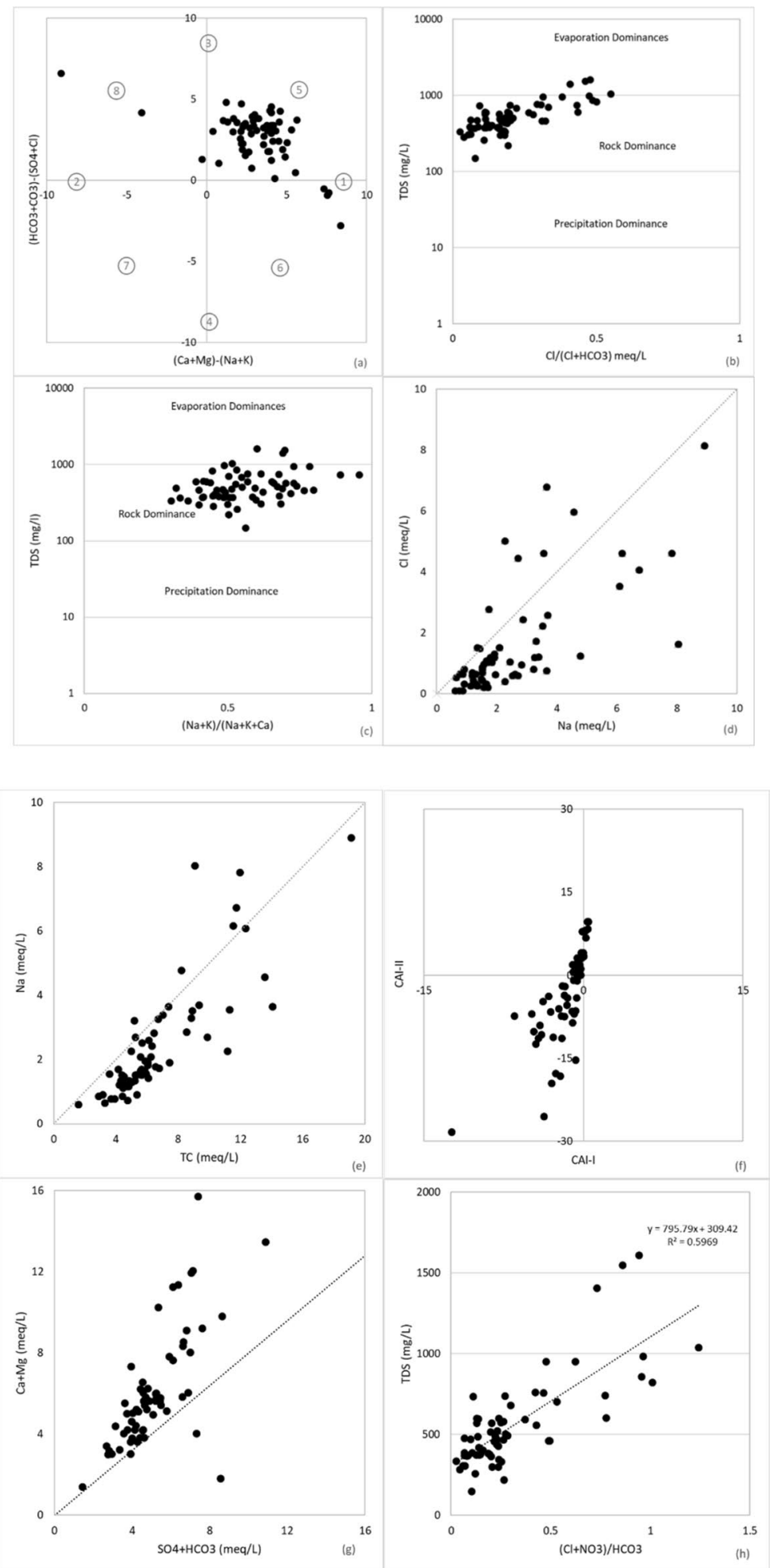

attributed due to other process, i.e., silicate weathering or cation exchange [23]. The high $\mathrm{Na}^{+}$ions suggest that apart from halite dissolution excess of $\mathrm{Na}^{+}$is contributed from the other sources (Fig. $3 \mathrm{~d}$ ). In case of silicate weathering along with the $\mathrm{Na}^{+}$it will also attribute high $\mathrm{HCO}_{3}{ }^{-}$in groundwater. The study area has dominance of
$\mathrm{HCO}_{3}{ }^{-}$, and to verify the influence of silicate weathering on groundwater quality, the scatter plot between the $\mathrm{Na}^{+}$and total cations is often used. Groundwater samples located below the 1:2 line, indicate that in addition to silicate weathering there is other hydrogeochemical 


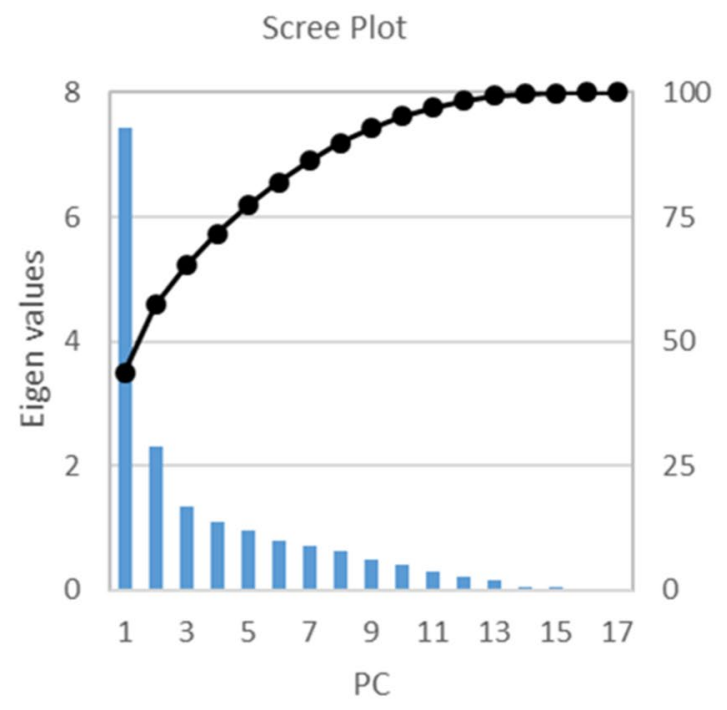

\section{Component Plot in Rotated Space}

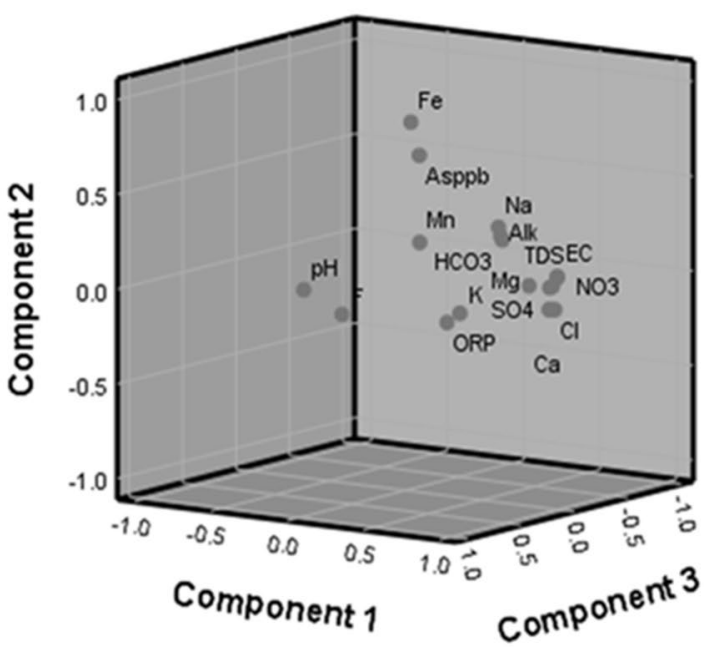

Fig. 4 Scree plot and component loading of PC 1, PC 2 and PC 3 in rotated space

processes, which significantly affects the $\mathrm{Na}^{+}$ions concentration in groundwater (Fig. 3e).

$\mathrm{CAl} 1=\mathrm{Cl}^{-}\left(\mathrm{Na}^{+}+\mathrm{K}^{+}\right) / \mathrm{Cl}^{-}$

$\mathrm{CAl} 2=\mathrm{Cl}^{-}-\left(\mathrm{Na}^{+}+\mathrm{K}^{+} \mathrm{SO}_{4}^{2-}+\mathrm{HCO}_{3}^{-}+\mathrm{CO}_{3}^{2-}+\mathrm{NO}_{3}^{-}\right.$

The chloro-alkalinity indices (CAl) are proposed as an indicator of specific ion exchange reaction in groundwater $[6,57]$. The chloro-alkalinity indices (CAI-I and CAI-II) are calculated using Eq. 7 and 8. The values of CAII and CAI II will be negative in case the $\mathrm{Na}^{+}$ions absorbed on the surface of fine-grained aquifer materials will be replaced by the $\mathrm{Ca} / \mathrm{Mg}$ ions, resulting in the increase of $\mathrm{Na}^{+}$ions in groundwater. However, the values of CAI I and CAI II will be positive when the $\mathrm{Na}^{+}$from groundwater will be exchanged by the adsorbed $\mathrm{Ca}^{2+}$ and $\mathrm{Mg}^{2+}$ ions from surface. As represented in Fig. 3f, the majority of groundwater sample falls on the lower left panel, indicating influence of reverse ions exchange resulting in the increase of $\mathrm{Na}^{+}$ in groundwater. A few samples also fall away from the left panel which suggests ion exchange, resulting in increase $\mathrm{Ca} / \mathrm{Mg}$ ions in groundwater. The ionic ratio of $\mathrm{Ca}^{2+}$ and $\mathrm{Mg}^{2+}$ ions is often used to determine the source of calcium and magnesium in groundwater [6]. In case of dolomite dissolution, the ratio of $\mathrm{Ca} / \mathrm{Mg}$ will be close to 1 , and greater values suggest dominance of silicate weathering on groundwater. In this present study the ratio of $\mathrm{Ca}^{2+}$ and $\mathrm{Mg}^{2+}$ suggests silicate weathering is dominant process controlling groundwater quality (Supplementary Fig. 1). Scatter plot between $\mathrm{Ca}+\mathrm{Mg}$ and $\mathrm{SO}_{4}+\mathrm{HCO}_{3}$ indicates the exchange of ions in groundwater and aquifer minerals. If the samples are close to the equiline, it suggests that dissolution of minerals such as calcite, dolomite or gypsum and ion exchange controls the groundwater quality and samples will lie toward right; however, in case of reverse ion exchange the points will shift toward left of the equiline. Most of the groundwater samples from this study fall toward left of the equiline, indicating reverse ion exchange controls the ionic concentration in groundwater (Fig. 3f). To investigate the influence of anthropogenic activities on groundwater quality TDS and $\left(\mathrm{NO}_{3}+\mathrm{Cl}\right) / \mathrm{HCO}_{3}$ molar ratio are used (Fig. $3 g)$. Significant positive relation $\left(R^{2}=0.59\right)$ between TDS and the molar ratio of these anions suggests influence the anthropogenic activity on groundwater quality $[58,59]$.

\subsection{Multivariate statistics}

The degree of correlation among the water quality parameter is analyzed by establishing the relationship between two variables. The value of correlation coefficient " $r$ " provides the information that how one parameter is associated with another; however, the sign indicates the positive or negative association. A positive strong correlation shows similar origin of ions; however, the week association between groundwater quality parameters indicates that the ions are independent from each other $[7,9,44]$. The value of $r>07$ is considered as strong; however, the $r$ between 0.5 and 0.7 is considered as moderate [44]. In this study $\mathrm{EC}$ shows strong positive correlation with $\mathrm{Cl}^{-}$, $\mathrm{HCO}_{3}{ }^{-}, \mathrm{SO}_{4}{ }^{-}, \mathrm{Mg}^{2+}, \mathrm{Ca}^{2+}$ and $\mathrm{Na}^{+}$; however, it has positive moderate association with $\mathrm{NO}_{3}{ }^{-}$. The strong correlation 
between these ions with EC indicates major influence of these ions of groundwater quality. The dissolution of aquifer minerals along with the rainwater interaction and anthropogenic activities prevailing in the study area has major influence on high $\mathrm{EC}$ in groundwater. Apart from $\mathrm{EC}, \mathrm{Cl}-\mathrm{Mg}, \mathrm{Cl}-\mathrm{Ca}, \mathrm{HCO}_{3}-\mathrm{Na}, \mathrm{SO}_{4}-\mathrm{Mg}$ are strongly correlated, while $\mathrm{HCO}_{3}-\mathrm{Cl}, \mathrm{SO}_{4}-\mathrm{Cl}, \mathrm{NO}_{3}-\mathrm{Cl}, \mathrm{Na}-\mathrm{Cl}, \mathrm{Mg}-\mathrm{HCO}_{3}, \mathrm{Ca}-\mathrm{HCO}_{3}$, $\mathrm{SO}_{4}-\mathrm{NO}_{3} \mathrm{Ca}-\mathrm{NO}_{3}, \mathrm{Na}-\mathrm{Mg}$ and $\mathrm{Ca}-\mathrm{Mg}$ have moderate correlation (Table 4). The positive association between these ions suggests similar source and indicates influence of anthropogenic and natural activities on groundwater.

Results of Q-mode HCA of the groundwater quality data indicate two major associations between 17 water quality variables (Supplementary Fig. 2). The 2 groups are obtained as a result of $\mathrm{HCA}$, and it has been clustered on the basis of major ions, which contributes to overall EC of the samples. Group 1 includes 49 samples, while Group 2 consists of 16 samples. The exclusivity of these two clusters is that the average concentrations of physico-chemical parameters of cluster 1 are less than cluster $2 . \mathrm{Ca}-\mathrm{HCO}_{3}$ is found as the most dominant group in cluster 1 , as $81.6 \%$ of the sample belongs to this water facies, while in cluster $2, \mathrm{Na}-\mathrm{HCO}_{3}$ is most dominant with $50 \%$ of the samples that have $\mathrm{Na}-\mathrm{HCO}_{3}$ water facies. The $\mathrm{EC}$ value depends on the concentration of dissolved ions, it has been found that the average value of EC in cluster 1 is $625.3 \mu \mathrm{S} / \mathrm{cm}$, while it increases in Group 2 up to $1375 \mu \mathrm{S} / \mathrm{cm}$.

Based on the eigen values $>1$, four major factors are extracted and sequentially, which cumulatively accounted for $71.7 \%$ of total variance in the data. PC 1 accounts for $43.7 \%$ of the total variance with highest eigen values of 7.44 (Table 5). It has strong positive loading of alkalinity, $\mathrm{EC}, \mathrm{Cl}^{-}, \mathrm{HCO}_{3}{ }^{-}, \mathrm{SO}_{4}{ }^{2-}, \mathrm{Na}^{+}, \mathrm{Mg}^{2+}$ and $\mathrm{Ca}^{2+}$ however moderate loading of $\mathrm{NO}_{3}{ }^{-}$. High loading of $\mathrm{EC}$ with these ions indicates influence of both anthropogenic and natural activities on groundwater quality. The significant positive loading of anions including $\mathrm{Cl}^{-}, \mathrm{NO}_{3}{ }^{-}$and $\mathrm{SO}_{4}{ }^{2-}$ indicates influence of anthropogenic activities [60]. The study area is a part of alluvial floodplain with extensive agriculture activities, discharge of fertilizers along with irrigation return flow might contributed $\mathrm{NO}_{3}{ }^{-}$and $\mathrm{Cl}^{-}$in groundwater; however, leaching of sewage and human waste might be responsible for high $\mathrm{SO}_{4}{ }^{2-}$. Apart from anions the high loading of cations including $\mathrm{Mg}^{2+}, \mathrm{Na}^{+}$and $\mathrm{Ca}^{2+}$ along with high $\mathrm{HCO}_{3}{ }^{-}$seems to be governed from the dissolution of aquifer minerals. PC 2 explains $13.54 \%$ of the total variance, and it has eigen value 2.3 , it has high loading of $\mathrm{Fe}$, As, and although not much significant but positive loading of $\mathrm{Mn}$, and $\mathrm{HCO}_{3}{ }^{-}$however negative loading of ORP. High and positive loading of $\mathrm{Fe}$ and $\mathrm{As}$ and negative loading of ORP indicate that dissolution of Fe bearing minerals in reducing environment is the source of As in groundwater. The dissolution of $\mathrm{FeOOH}$ is considered as the major source of groundwater As [10, 31, 39, 40]. Study area is a part of alluvial floodplain of river Ganga poorly drained and has a high organic matter which provides a favorable condition for microbially mediated reduction of iron/ manganese oxides/oxyhydroxides resulting release of $\mathrm{Fe}$ and adsorbed As into groundwater [31, 40]. However, the concentration of As is found well below the WHO guideline for drinking. PC 3 explains $7.9 \%$ of the variance with eigen value 1.3 , and PC 4 explains $6.4 \%$ of variance with eigen value 1.1, respectively. High and positive loading of $\mathrm{F}^{-}$along with $\mathrm{pH}$ in $\mathrm{PC} 3$ suggests dissolution of fluoridebearing minerals in alkaline condition. In case of hydrolysis of silicate minerals the concentration of cations, especially, $\mathrm{Ca}^{2+}, \mathrm{Na}^{+}$and $\mathrm{K}^{+}$, should increase simultaneously with $\mathrm{F}^{-}$[61]; however, the negative association between $\mathrm{F}^{-}$and $\mathrm{Ca}^{2+}$ is found in the study region which suggests the dissolution of fluorite as a source of $\mathrm{F}^{-}$ions in groundwater [31]. High concentration of $\mathrm{HCO}_{3}{ }^{-}$is also found which may favor the dissolution of fluoride and precipitation of carbonate minerals, i.e., calcite and dolomite [9]. lon exchange will take place between $\mathrm{OH}^{-}$and $\mathrm{F}^{-}$which will result in increased concentration of $\mathrm{F}^{-}$in groundwater; however, in addition the reverse ion exchange may limit the $\mathrm{Ca}^{2+}$ ions in groundwater [9].

\subsection{Suitability of groundwater for drinking}

The groundwater quality parameters were compared with the WHO guidelines for drinking and human consumption. Among the major ions $32.3 \%$ of the groundwater samples exceed the recommended limits for $\mathrm{HCO}_{3}{ }^{-}, 6.2 \%$ has high $\mathrm{EC}$, and $3.1 \%$ has high $\mathrm{Na}^{+}$and $\mathrm{K}^{+}$; however, the $\mathrm{pH}$ of all the groundwater samples is found within the permissible limits. Based on the health risk and severity high $\mathrm{F}^{-}$along with $\mathrm{Fe}$ and $\mathrm{Mn}$ is found as major concern as $15.4 \%, 52.3 \%$ and $24.6 \%$ samples exceeds the WHO guidelines, respectively. High concentration of $\mathrm{F}^{-}$is mostly attributed due to the natural activity, i.e., weathering and dissolution of aquifer minerals in favorable environment however anthropogenic activity as fertilizers may also contribute $\mathrm{F}^{-}$in groundwater. At certain amount, $\mathrm{F}^{-}$is essential for the formation of bones and teeth; however, the exceeding concentration $\mathrm{F}^{-}$in groundwater may cause bone deformation, dental caries along with dental and skeletal fluorosis $[29,30]$. Long-term exposure of high $\mathrm{F}^{-}$can cause intellectual damage in children and mental retardation along with loss of fertility, miscarriage and birth abnormalities [29]. Similarly the exceeding Mn concentration beyond the permissible limits may also have severe health risks [62].

Furthermore the groundwater quality was also evaluated through WQI and WPI (Fig. 5). WQI is a dimensionless values which classifies water into 5 major classes, i.e., (a) WQI $<50$ represents excellent water, (b) WQI 50-100, 


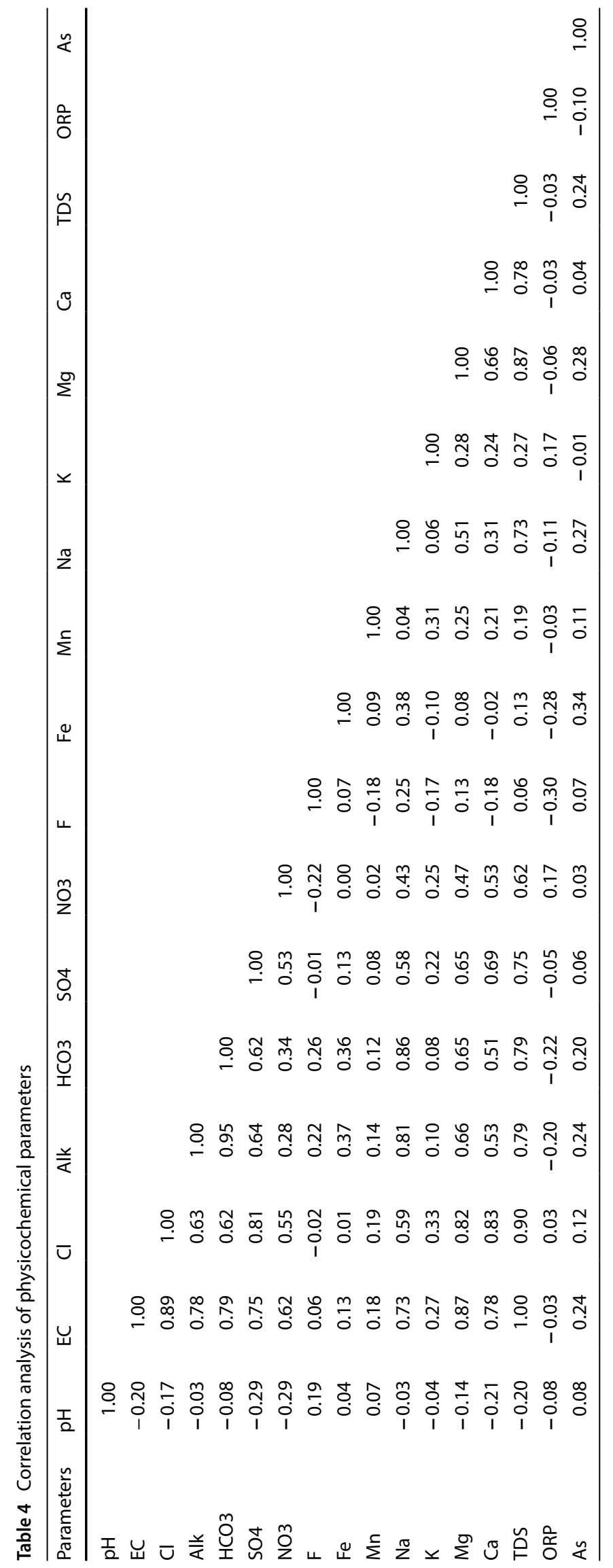


Table 5 Factor loading of each of the principle components

\begin{tabular}{|c|c|c|c|c|}
\hline Water quality variable & PC 1 & PC 2 & PC 3 & PC 4 \\
\hline $\mathrm{pH}$ & -0.234 & 0.013 & 0.619 & 0.348 \\
\hline EC & 0.963 & 0.109 & -0.048 & 0.117 \\
\hline $\mathrm{Cl}^{-}$ & 0.914 & -0.078 & -0.095 & 0.201 \\
\hline Alk & 0.810 & 0.350 & 0.264 & -0.017 \\
\hline $\mathrm{HCO}_{3}^{-}$ & 0.823 & 0.334 & 0.267 & -0.079 \\
\hline $\mathrm{SO}_{4}^{2-}$ & 0.839 & 0.022 & -0.152 & -0.033 \\
\hline $\mathrm{NO}_{3}^{-}$ & 0.622 & -0.041 & -0.490 & -0.027 \\
\hline $\mathrm{F}^{-}$ & 0.135 & -0.055 & 0.787 & -0.283 \\
\hline $\mathrm{Fe}$ & 0.082 & 0.851 & 0.067 & -0.091 \\
\hline $\mathrm{Mn}$ & 0.089 & 0.207 & -0.006 & 0.791 \\
\hline $\mathrm{Na}^{+}$ & 0.746 & 0.382 & 0.193 & -0.152 \\
\hline $\mathrm{K}^{+}$ & 0.245 & -0.175 & -0.160 & 0.638 \\
\hline $\mathrm{Mg}^{2+}$ & 0.844 & 0.061 & 0.047 & 0.247 \\
\hline $\mathrm{Ca}^{2+}$ & 0.788 & -0.108 & -0.221 & 0.204 \\
\hline TDS & 0.965 & 0.103 & -0.043 & 0.123 \\
\hline ORP & -0.057 & -0.299 & -0.471 & 0.134 \\
\hline As(ppb) & 0.110 & 0.673 & 0.027 & 0.173 \\
\hline Eigen value & 7.445 & 2.302 & 1.345 & 1.103 \\
\hline$\%$ of variance explained & 43.794 & 13.542 & 7.909 & 6.488 \\
\hline Cumulative \% & 43.794 & 57.336 & 65.245 & 71.732 \\
\hline
\end{tabular}

good water quality, (c) WQI values 100-200, poor water, (d) WQI 200-300, very poor and (e) WQI > 300 not suitable for drinking and domestic use [46]. WQI values vary from 14.4 to 157.2 with an average of 51.1. In total, 37 out of 65 samples (56.9\%) belong to the excellent water quality, 24 out of 65 (36.9\%) belong to good water quality, and 4 out of 65 , i.e., $6.1 \%$ samples, are categorized under poor water quality (Table 6). However none of the groundwater falls under very poor or unsuitable category. Similar to WQI, WPI is also used to understand the pollution load, the values of WPI suggest four water quality as: $\mathrm{WPI}<0.5$ corresponds to excellent quality, WPI $0.5-0.75$ signifies good water; (c) WPI $0.75-1.0$ suggests moderately polluted; however, WPI exceeding 1 indicates severely polluted water [48]. The results of WPI indicate that $43.07 \%$ samples ( 28 out of 65 ) are under excellent water category, i.e., $\mathrm{WPI}<0.5,33.8 \%$ samples, i.e., 22 out of 65 are under good water with WPI $0.5-0.75,13.8 \%$, i.e., 9 out of 65 samples lies under moderately polluted and $9.2 \%$, i.e., 6 out of 65 are under highly polluted water category and not recommended for human consumption. The details about the spatial distribution of the WPI and WQI are provided in Table 6.

\subsection{Suitability of groundwater for irrigation}

The study area is under extensive agriculture as it is a part of fertile alluvial floodplain of river Ganga and its tributaries. The concentration of EC in irrigation water is important as it has a direct impact on plants metabolism, and it is also evident that high EC in irrigation water may reduce the fertility of soil by reducing its permeability and aeration capacity. The irrigation water is classified in five major classes based on the EC concentration. In this study, $1.5 \%$, i.e., 1 out of 65 collected sample, falls under excellent category; however, majority of the samples, 36 out of 65 , i.e., $55.3 \%$ falls under the good water category, $40 \%$ of the samples falls under just permissible, and $3 \%$ samples are doubtful for agricultural use (Table 6). Based on the classification of $\mathrm{Cl}^{-}$in irrigation water it has been found that $78.4 \%$ of groundwater samples are safe for all crops; however, $7.69 \%$ samples are sensitive and $12.3 \%$ are moderately suitable for irrigation use (Table 6). High concentration of $\mathrm{Cl}^{-}$in irrigation water may burn the leaf and alter the photosynthesis pattern in plants resulting
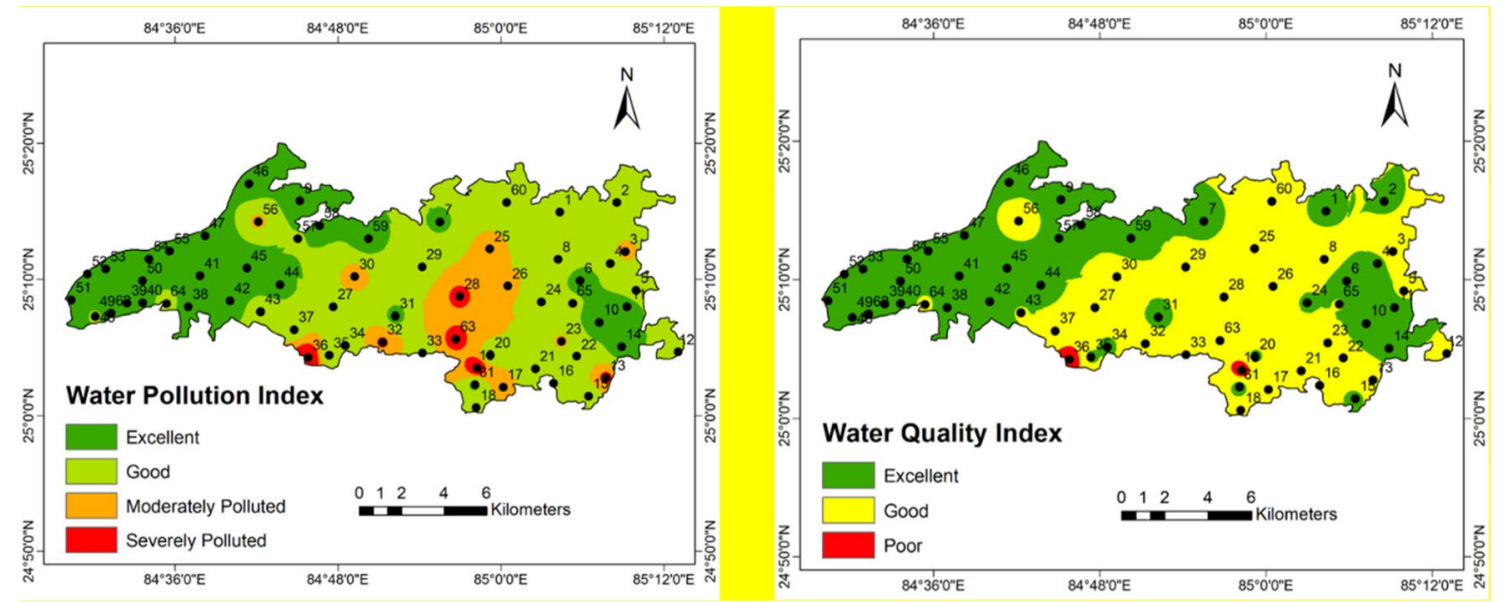

Fig. 5 Spatial distribution of water quality index and water pollution index in study area 
Table 6 Summary of irrigation water quality indices in study area and \% of samples falling in each class and their spatial details

\begin{tabular}{|c|c|c|c|c|}
\hline Indices & Values & Suitability for drinking and irrigation & $\begin{array}{l}\% \text { of samples } \\
\text { from current } \\
\text { study }\end{array}$ & Details of spatial location of each category \\
\hline \multirow[t]{5}{*}{ WQI } & $<50$ & Excellent & 56.9 & $\begin{array}{l}1,2,4,6-11,14,15,20,24,31,34,35,38-42,44-55 \\
57-59,62\end{array}$ \\
\hline & $50-100$ & Good & 36.9 & $\begin{array}{l}3,5,12,13,16-18,22,23,25-27,29,30,32,33,37,43 \\
56,60,61,63-65\end{array}$ \\
\hline & $100-200$ & Poor & 6.1 & $19,21,28,36$ \\
\hline & $200-300$ & Very Poor & - & - \\
\hline & $>300$ & Unsuitable for use & - & - \\
\hline \multirow[t]{4}{*}{ WPI } & $<0.50$ & Excellent & 43.07 & $4,6-11,14,31,34,35,38-42,44-51,53,54,58,59$ \\
\hline & $0.50-0.75$ & Good & 33.8 & $\begin{array}{l}1,2,5,12,15,16,18,20,22,24,27,29,33,37,43,52,55, \\
57,60,62,63,65\end{array}$ \\
\hline & $0.75-1.0$ & Moderately Polluted & 13.8 & $3,17,23,25,26,30,56,61,64$ \\
\hline & $>1.0$ & Severely polluted & 9.2 & $13,19,21,28,32,36$ \\
\hline \multirow[t]{4}{*}{ SAR } & $<10$ & Excellent & 98.5 & $1-27,29-65$ \\
\hline & $10.0-18$ & Good & 1.5 & 28 \\
\hline & $18-26$ & Doubtful & - & - \\
\hline & $>26$ & Unsuitable & - & - \\
\hline \multirow[t]{3}{*}{ RSC } & $<1.25$ & Safe for use & 97 & $1-26,29-65$ \\
\hline & $1.25-2.5$ & Can be used after treatment & - & - \\
\hline & $>2.5$ & Unfit & 3 & 27,28 \\
\hline \multirow[t]{3}{*}{ RSBC } & $<1.25$ & Safe for use & 61.5 & $\begin{array}{l}1,3,5,6,9-12,14,15,18,20,21,23,26,29-33,35,37,38,41- \\
45,47-50,52-54,56-59,64\end{array}$ \\
\hline & $1.25-2.5$ & Can be used after treatment & 27.6 & $4,7,8,13,16,17,22,24,34,39,40,46,51,55,60,61,62,65$ \\
\hline & $>2.5$ & Unfit & 10.7 & $2,19,25,27,28,36,63$ \\
\hline \multirow[t]{2}{*}{$\mathrm{PI}$} & $25 \%$ or more & Suitable & 100 & $1-65$ \\
\hline & $25 \%$ & Unsuitable & - & - \\
\hline \multirow[t]{2}{*}{ MAR } & $>50$ & Unsuitable & 12.3 & $2,19,25,27,32,55,60,63$ \\
\hline & $<50$ & Safe for use & 87.7 & $1,3-18,26,28-31,33-54,46-59,61,62,64,65$ \\
\hline \multirow[t]{2}{*}{ Kelly's Ratio } & $>1$ & Unsuitable & 3 & 27,28 \\
\hline & $<1$ & Safe for use & 97 & $1-26,29-65$ \\
\hline \multirow[t]{5}{*}{$\% \mathrm{Na}$} & $<20$ & Excellent & 18.4 & $1,6,12,18,20,23,42,44,49,52,56,57$ \\
\hline & $20-40$ & Good & 70.7 & $\begin{array}{l}1-5,7-11,1-15,17,21,22,25,26,29-35,37-41,43 \\
45-48,50,51,53-55,58-63,65\end{array}$ \\
\hline & $40-60$ & Permissible & 7.6 & $16,19,24,36,64$ \\
\hline & $60-80$ & Doubtful & 1.5 & 27 \\
\hline & $>80$ & Unsuitable & 1.5 & 28 \\
\hline \multirow[t]{5}{*}{$\mathrm{EC}(\mu \mathrm{S} / \mathrm{cm})$} & $<250$ & Excellent & 1.5 & 47 \\
\hline & $250-750$ & Good & 55.3 & $\begin{array}{l}1,2,6-11,14,16,22,24,31,33-35,38-42,44-46,49-59, \\
\quad 65\end{array}$ \\
\hline & $750-2250$ & Permissible & 40 & $3-5,12,15,17-21,23,25-30,36,37,43,48,60-64$ \\
\hline & $2250-3000$ & Doubtful & 3 & 13,32 \\
\hline & $>3000$ & Unsuitable & - & - \\
\hline \multirow[t]{4}{*}{$\mathrm{Cl}(\mathrm{mg} / \mathrm{l})$} & $<70$ & Safe for all crops & 78.4 & $\begin{array}{l}1,2,4,6-12,14,16-18,22,24,27-29,31,33,34-36 \\
38-63,65\end{array}$ \\
\hline & $70-140$ & Sensitive plants might show injuries & 7.69 & $3,15,20,25,37$ \\
\hline & $141-350$ & Moderately suitable & 12.3 & $5,13,19,21,23,26,30,32,64$ \\
\hline & $>350$ & Not suitable & - & - \\
\hline
\end{tabular}


low productivity [63]. The concentration of K exceeds the BIS guidelines for irrigation in $9.6 \%$ of the samples. Sample numbers $23,32,33,37$ and 46 have high potassium which makes it unsuitable for irrigation.

The groundwater quality variables are used to calculate the irrigation water quality indices, i.e., SAR, $\mathrm{Na} \%$, $\mathrm{MH}, \mathrm{KR}, \mathrm{RSBC}, \mathrm{MAR}, \mathrm{PI}, \mathrm{RSC}$ using the standard formula and ionic ratio provided in Table 2 . The calculated values of most of these indices are within the permissible limits; however, based on RSBC values $27.6 \%$ of the samples needs proper treatment and $10.7 \%$ are unfit for irrigation (Table 6). Similarly, $12.3 \%$ of samples are unsuitable based on the MAR values, 3\% are unfit based on RSC and $\mathrm{KR}$, and $1.5 \%$ samples are under doubtful and unsuitable based on $\mathrm{Na} \%$ values. High values of these indices may have negative impacts on crop productivity and soil fertility $[64,65]$. USSL diagram is plotted to determine the suitability of groundwater for irrigation as it evaluates the groundwater quality-based SAR values and salinity hazard, i.e., EC. The USSL diagram infers that $72.5 \%$ of the samples has medium salinity hazard and low sodium hazard, and this water is moderately suitable for irrigation (Fig. 6). However $21.5 \%$ samples have high salinity hazard with low sodium hazard, and $3 \%$ has very high salinity hazard with low sodium hazard, and it is not recommended for irrigation.

\section{Conclusion}

The study evaluates the groundwater quality and its evolution in middle Gangetic floodplain. The study area is under extensive agriculture and groundwater is mostly used for irrigation and drinking water, so the suitability of groundwater for drinking and irrigation use is also evaluated. This study infers that the ionic evolution of groundwater is controlled by both natural and anthropogenic activities. The excess of $\mathrm{EC}$ and other ions including $\mathrm{Cl}, \mathrm{HCO}_{3}, \mathrm{Na}^{+}$, $\mathrm{K}^{+}$makes the groundwater unfit. However, high $\mathrm{F}$ and $\mathrm{Fe}$ is found as the major public health concern due to their sever health implications. Chadha diagram infers that $\mathrm{Ca}$ $\mathrm{Mg}-\mathrm{HCO}_{3}$ is the most dominant water type followed by $\mathrm{Na}-\mathrm{HCO}_{3}, \mathrm{Mg}-\mathrm{HCO}_{3}$ and $\mathrm{Mg}-\mathrm{SO}_{4}$ water types. Rock water interaction seems as the major controlling factor for groundwater quality. Silicate weathering along with the ion exchange is major hydrogeochemical process responsible for the ionic species in groundwater. The results of chemometric analysis also support the findings of hydrogeochemical investigations. The overall water quality for drinking was evaluated using WQI and WPI, and the results of WQI values suggest that $6.1 \%$ samples belong to poor water class; however, based on WPI $23 \%$ samples belong to moderately polluted or severely polluted categories. Therefore, it needs to be treated before being used for
Fig. 6 USSL diagram for water sample from study area

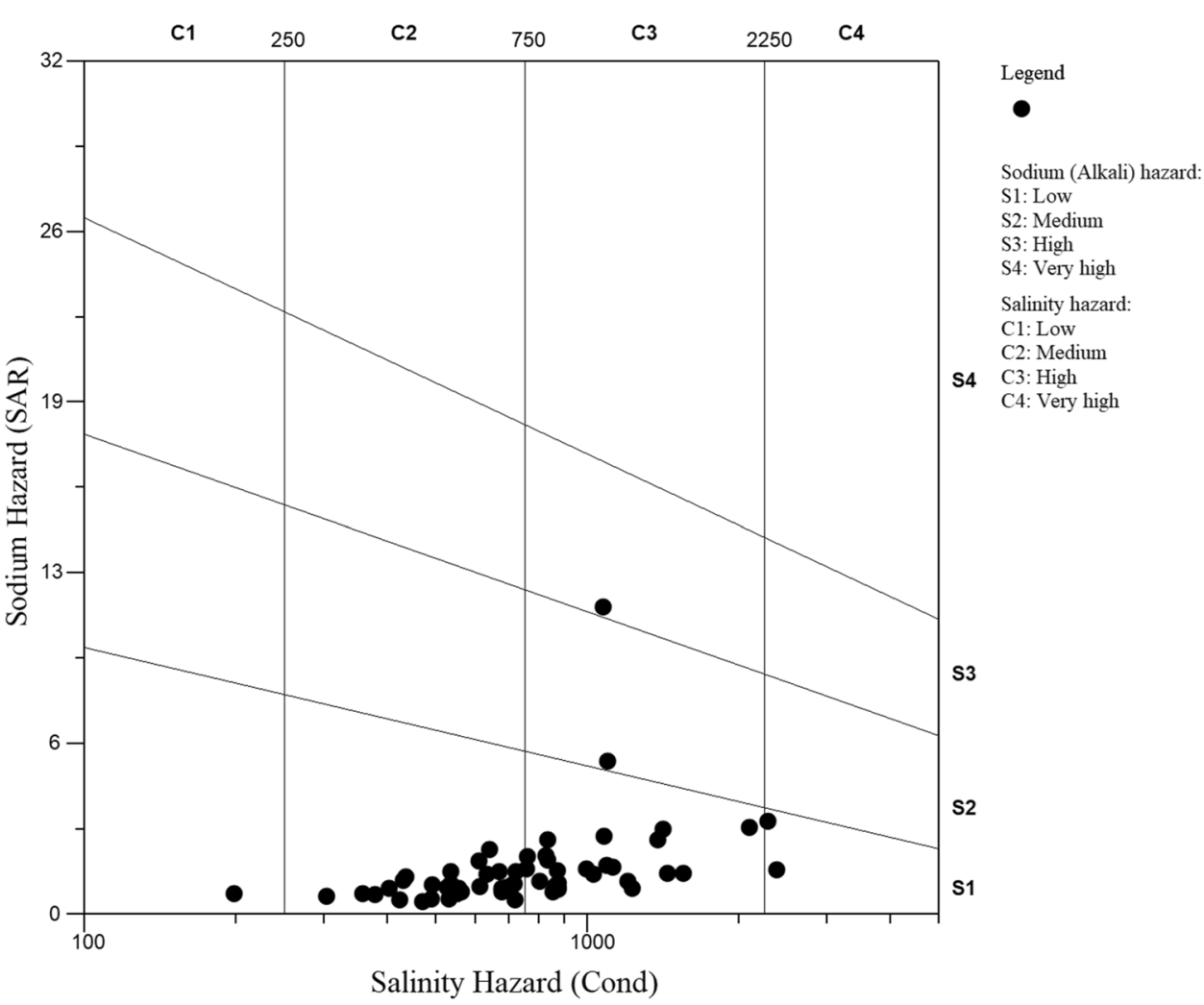

SN Applied Sciences A SPRINGER NATURE journa 
drinking or supply to households. Although majority of groundwater samples are suitable for irrigation; however, the groundwater exceeding the limits of RSBC, MAR, RSC and with high salinity hazard with low sodium hazard needs proper attention before used for irrigation. The testing of wells and alternate option for drinking water supply in fluoride affected regions is advised to reduce exposure. The outcomes of this study with spatial distribution maps of water quality parameters and indices can be used for prioritizing the area for effective management of groundwater resources in the study region.

\section{Compliance with ethical standards}

Conflict of interest The authors declare that there is no conflict of interest.

Availability of data and material The data are original and not published or submitted anywhere else.

Open Access This article is licensed under a Creative Commons Attribution 4.0 International License, which permits use, sharing, adaptation, distribution and reproduction in any medium or format, as long as you give appropriate credit to the original author(s) and the source, provide a link to the Creative Commons licence, and indicate if changes were made. The images or other third party material in this article are included in the article's Creative Commons licence, unless indicated otherwise in a credit line to the material. If material is not included in the article's Creative Commons licence and your intended use is not permitted by statutory regulation or exceeds the permitted use, you will need to obtain permission directly from the copyright holder. To view a copy of this licence, visit http://creativecommons .org/licenses/by/4.0/.

\section{References}

1. UNEP (1999) Global environment outlook 2000. USGS, Earthscan UK

2. Adimalla N, Venkatayogi S (2018) Geochemical characterization and evaluation of groundwater suitability for domestic and agricultural utility in semi-arid region of Basara, Telangana State South India. Appl Water Sci 8:44. https://doi.org/10.1007/s1320 1-018-0682-1

3. Adimalla N, Dhakate R, Kasarla A, Taloor AK (2020) Appraisal of groundwater quality for drinking and irrigation purposes in Central Telangana India. Groundw Sustain Dev 10:100334. https ://doi.org/10.1016/j.gsd.2020.100334

4. Saeid S, Chizari M, Sadighi H, Bijani M (2018) Assessment of agricultural groundwater users in Iran: a cultural environmental bias. Hydrogeol J 26(1):285-295. https://doi.org/10.1007/s1004 0-017-1634-9

5. Santucci L, Carol E, Tanjal C (2018) Industrial waste as a source of surface and groundwater pollution for more than half a century in a sector of the Río de la Plata coastal plain (Argentina). Chemosphere 206:727-735. https://doi.org/10.1016/j.chemospher e.2018.05.084

6. Kumar A, Roy SS, Singh CK (2020) Geochemistry and associated human health risk through potential harmful elements (PHEs) in groundwater of the Indus basin. India Environ Earth Sci 79(4):86. https://doi.org/10.1007/s12665-020-8818-7
7. Kumar A, Singh CK (2015) Characterization of hydrogeochemical processes and fluoride enrichment in groundwater of Southwestern Punjab. Water Qual Expo Health 7(3):373-387. https:// doi.org/10.1007/s12403-015-0157

8. Singh G, Rishi MS, Herojeet R, Kaur L, Sharma K (2020) Multivariate analysis and geochemical signatures of groundwater in the agricultural dominated taluks of Jalandhar district, Punjab India. J Geochem Explor 208:106395. https://doi.org/10.1016/j.gexpl o.2019.106395

9. Singh CK, Kumar A, Shashtri S, Kumar A, Kumar P, Mallick J (2017) Multivariate statistical analysis and geochemical modeling for geochemical assessment of groundwater of Delhi, India. J Geochem Explor 175:59-71. https://doi.org/10.1016/j. gexplo.2017.01.001

10. Kumar A, Singh CK (2020) Arsenic enrichment in groundwater and associated health risk in Bari doab region of Indus basin, Punjab India. Environ Poll 256:113324. https://doi. org/10.1016/j.envpol.2019.113324

11. Kadam A, Wagh V, Umrikar B, Sankhua R (2020) An implication of boron and fluoride contamination and its exposure risk in groundwater resources in semi-arid region Western India. Environ Dev Sustain 7:7033-7056. https://doi.org/10.1007/ s10668-019-00527-w

12. Li C, Gao X, Wang Y (2015) Hydrogeochemistry of high-fluoride groundwater at Yuncheng Basin, northern China. Sci Total Environ 508:155-165. https://doi.org/10.1016/j.scito tenv.2014.11.045

13. LiuHothDrebenstedtSunXu PNCYZ (2017) Hydro-geochemical paths of multi-layer groundwater system in coal mining regions-Using multivariate statistics and geochemical modelling approaches. Sci Total Environ 601:1-14. https://doi. org/10.1016/j.scitotenv.2017.05.146

14. Lapworth DJ, Krishan G, MacDonald AM, Rao MS (2017) Groundwater quality in the alluvial aquifer system of northwest India: new evidence of the extent of anthropogenic and geogenic contamination. Sci Total Environ 599:1433-1444. https://doi.org/10.1016/j.scitotenv.2017.04.223

15. MacDonald AM, Bonsor HC, Ahmed KM, Burgess WG, Basharat M, Calow RC, Dixit A, Foster SS, Gopal K, Lapworth DJ, Lark RM (2016) Groundwater quality and depletion in the IndoGangetic Basin mapped from in situ observations. Nat Geosci 9(10):762-766. https://doi.org/10.1038/ngeo2791

16. Abtahi M, Golchinpour N, Yaghmaeian K, Rafiee M, Jahangirirad M, Keyani A, Saeedi R (2015) A modified drinking water quality index (DWQI) for assessing drinking source water quality in rural communities of Khuzestan Province Iran. Ecol Indic 53:283-291. https://doi.org/10.1016/j.ecolind.2015.02.009

17. Mukate S, Wagh V, Panaskar D, Jacobs JA, Sawant A (2019) Development of new integrated water quality index (IWQI) model to evaluate the drinking suitability of water. Ecol Indic 101:348-354. https://doi.org/10.1016/j.ecolind.2019.01.034

18. Horton RK (1965) (1965) An index number system for rating water quality. J Water Pollut Control Fed 37:300-306

19. Wagh VM, Mukate SV, Panaskar DB, Muley AA, Sahu UL (2019) Study of groundwater hydrochemistry and drinking suitability through water quality index (WQI) modelling in Kadava river basin India. SN Appl Sci 1(10):1-6. https://doi.org/10.1007/ s42452-019-1268-8

20. Singh S, Ghosh NC, Krishan G, Kumar S, Gurjar S, Sharma MK (2019) Development of indices for surface and ground water quality assessment and characterization for Indian conditions. Environ Monit Assess 191(3):1-20. https://doi.org/10.1007/ s10661-019-7276-8

21. Goher ME, Hassan AM, Abdel-Moniem IA, Fahmy AH, El-sayed SM (2014) Evaluation of surface water quality and heavy metal 
indices of Ismailia Canal, Nile River Egypt. Egypt J Aquat Res 40(3):225-233. https://doi.org/10.1016/j.ejar.2014.09.001

22. Singh CK, Shashtri S, Mukherjee S, Kumari R, Avatar R, Singh A, Singh RP (2011) Application of GWQI to assess effect of land use change on groundwater quality in lower Shiwaliks of Punjab: remote sensing and GIS based approach. Wat Res Manag 25(7):1881-1898. https://doi.org/10.1007/s11269-011-9779-0

23. Gao Y, Qian H, Ren W, Wang H, Liu F, Yang F (2020) Hydrogeochemical characterization and quality assessment of groundwater based on integrated-weight water quality index in a concentrated urban area. J Clean Prod. https://doi. org/10.1016/j.jclepro.2020.121006

24. Bora M, Goswami DC (2017) Water quality assessment in terms of water quality index (WQI): case study of the Kolong River, Assam India. Appl Water Sci 7(6):3125-3135. https://doi. org/10.1007/s13201-016-0451-y

25. Wagh V, Mukate S, Muley A, Kadam A, Panaskar D, Varade A (2020) Study of groundwater contamination and drinking suitability in basaltic terrain of Maharashtra, India through PIG and multivariate statistical techniques. Water Sci Tech-W Sup 69(4):398-414. https://doi.org/10.2166/aqua.2020.108

26. Shah SM, Mistry NJ (2013) Groundwater quality assessment for irrigation use in Vadodara District, Gujarat India. Int J Agr Biol Eng 7(7):719-724. https://doi.org/10.5281/zenodo.1087474

27. Khanoranga KS (2018) An assessment of groundwater quality for irrigation and drinking purposes around brick kilns in three districts of Balochistan province, Pakistan, through water quality index and multivariate statistical approaches. J Geochem Explor 197:14-26. https://doi.org/10.1016/j.gexplo.2018.11.007

28. Maity S, Biswas R, Sarkar A (2020) Comparative valuation of groundwater quality parameters in Bhojpur Bihar for arsenic risk assessment. Chemosphere 259:127398. https://doi. org/10.1016/j.chemosphere.2020.127398

29. Zhang L, Huang D, Yang J, Wei X, Qin J, Ou S, Zhang Z, Zou Y (2017) Probabilistic risk assessment of Chinese residents' exposure to fluoride in improved drinking water in endemic fluorosis areas. Environ Pollut 222:118-125. https://doi.org/10.1016/j. envpol.2016.12.074

30. Yadav KK, Kumar S, Pham QB, Gupta N, Rezania S, Kamyab H, Talaiekhozani A (2019) Fluoride contamination, health problems and remediation methods in Asian groundwater: a comprehensive review. Ecotoxicol Environ Saf 182:109362. https:// doi.org/10.1016/j.ecoenv.2019.06.045

31. Singh CK, Kumar A, Bindal S (2018) Arsenic contamination in Rapti River Basin, Terai region of India. J Geochem Explor 192:120-131. https://doi.org/10.1016/j.gexplo.2018.06.010

32. Simsek C, Gunduz O (2007) IWQ index: a GIS-integrated technique to assess irrigation water quality. Environ Monit Assess 128(1-3):277-300. https://doi.org/10.1007/s10661-006-9312-8

33. Wang S, Wu W, Liu F, Liao R, Hu Y (2017) Accumulation of heavy metals in soil-crop systems: a review for wheat and corn. Environ Sci Pollut Res 24(18):15209-15225. https://doi.org/10.1007/ s11356-017-8909-5

34. Mondal D, Rahman MM, Suman S, Sharma P, Siddique AB, Rahman MA, Ghosh A (2020) Arsenic exposure from food exceeds that from drinking water in endemic area of Bihar. India Sci Total Environ 754:142082. https://doi.org/10.1016/j.scito tenv.2020.142082

35. Abbasnia A, Yousefi N, Mahvi AH, Nabizadeh R, Radfard M, Yousefi M, Alimohammadi M (2019) Evaluation of groundwater quality using water quality index and its suitability for assessing water for drinking and irrigation purposes: case study of Sistan and Baluchistan province (Iran). Hum Ecol Risk Assess 25(4):988-1005. https://doi.org/10.1007/s13201-018-0682-1

36. Lapworth DJ, Das P, Shaw A, Mukherjee A, Civil W, Petersen JO, Gooddy DC, Wakefield O, Finlayson A, Krishan G, Sengupta P
(2018) Deep urban groundwater vulnerability in India revealed through the use of emerging organic contaminants and residence time tracers. Environ Poll 240:938-949. https://doi. org/10.1016/j.envpol.2018.04.053

37. Donselaar ME, Bhatt AG, Ghosh AK (2017) On the relation between fluvio-deltaic flood basin geomorphology and the wide-spread occurrence of arsenic pollution in shallow aquifers. Sci Total Environ 574:901-913. https://doi.org/10.1016/j. scitotenv.2016.09.074

38. Central Groundwater Board (CGWB), Ground Water Information Booklet Jehanabad District (2013) Bihar State. http://cgwb.gov. in/District_Profile/Bihar/Jehanabad.pdf

39. Acharya SK (2005) Arsenic levels in groundwater from quaternary alluvium in the ganga plain and the Bengal basin, Indian subcontinent: insights into influence of stratigraphy. Gondwana Res 8(1):55-66. https://doi.org/10.1016/S1342 -937X(05)70262-8

40. Sahu S, Raju NJ, Saha D (2010) Active tectonics and geomorphology in the Sone-Ganga alluvial tract in mid-Ganga Basin, India. Quatern Int. https://doi.org/10.1016/j.quain t.2010.05.023

41. Ganguli SS, Singh S (2016) Delineation of Holocene-Pleistocene aquifer system in parts of Middle Ganga Plain, Bihar, Eastern India through DC resistivity survey. Appl Water Sci 6(4):359-370. https://doi.org/10.1007/s13201-014-0220-8

42. APH (2008) Standard methods for the examination of water and waste water, 21 st edn. American Public Health Association, Washington DC

43. Bodrud-Doza M, Islam AT, Ahmed F, Das S, Saha N, Rahman MS (2016) Characterization of groundwater quality using water evaluation indices, multivariate statistics and geostatistics in central Bangladesh. Wat Sci 30(1):19-40. https://doi. org/10.1016/j.wsj.2016.05.001

44. Wagh VM, Panaskar DB, Jacobs JA, Mukate SV, Muley AA, Kadam AK (2019) Influence of hydro-geochemical processes on groundwater quality through geostatistical techniques in Kadava River basin Western India. Arab J Geosci 12(1):7. https ://doi.org/10.1007/s12517-018-4136-8

45. Kaiser HF (1958) The varimax criterion for analytic rotation in factor analysis. Psychometrika 23(3):187-200. https://doi. org/10.1007/BF02289233

46. Mallick J, Kumar A, Almesfer MK, Alsubih M, Singh CK, Ahmed M, Khan RA (2021) An index-based approach to assess groundwater quality for drinking and irrigation in Asir region of Saudi Arabia. Arab J Geosci 14(3):1-7. https://doi.org/10.1007/s1251 7-021-06506-8

47. World Health Organization (2012) Guidelines for drinking-water quality. WHO, Geneva

48. Hossain M, Patra PK (2020) Water pollution index-A new integrated approach to rank water quality. Ecol Indic 117:106668. https://doi.org/10.1016/j.ecolind.2020.106668

49. Wilcox (1955) Classification and use of irrigation water. USDA Circ. 696, Washington DC. https://www.ars.usda.gov/arsuserfil es/20360500/pdf_pubs/P0192.pdf

50. Kelly WP (1963) Use of saline irrigation water. Soil Sciences 95(4):355-391

51. Subramanian V, Saxena K (1983) Hydro-geochemistry of groundwater in the Delhi region of India, relation of water quality and quantity. Proceedings of the Hamberg symposium IAHS 146:307-316

52. Davis SN, Dewiest RJM (1967) Hydrogeology. Wiley, New York

53. Walker GR, Jolly ID, Cook PG (1991) A new chloride leaching approach to the estimation of diffuse recharge following a change in land use. J Hydrol 128(1-4):49-67. https://doi. org/10.1016/0022-1694(91)90131-Z 
54. Elisante E, Muzuka AN (2017) Occurrence of nitrate in Tanzanian groundwater aquifers: a review. Appl Wat Sci 7(1):71-87. https ://doi.org/10.1007/s13201-015-0269-z

55. Chadha DK (1999) A proposed new diagram for geochemical classification of natural waters and interpretation of chemical data. Hydrogeol 7(5):431-439. https://doi.org/10.1007/s1004 00050216

56. Gibbs RJ (1970) Mechanism controlling world water chemistry. Sciences 170:795-840. https://doi.org/10.1126/scien ce.170.3962.1088

57. Schoeller H (1977) Geochemistry of groundwater. Ch. 15, pp 1-18 In: Groundwater studies-An International guide for research and practice, Paris: UNESCO

58. Jalali M (2009) Geochemistry characterization of groundwater in an agricultural area of Razan, Hamadan Iran. Environ Geol 56(7):1479-1488. https://doi.org/10.1007/s00254-008-1245-9

59. Barzegar R, Moghaddam AA, Tziritis E, Fakhri MS, Soltani S (2017) Identification of hydrogeochemical processes and pollution sources of groundwater resources in the Marand plain, northwest of Iran. Environ Earth Sci 76(7):297. https://doi. org/10.1007/s12665-017-6612-y

60. Kumar R, Mittal S, Sahoo PK, Sahoo SK (2020) Source apportionment, chemometric pattern recognition and health risk assessment of groundwater from southwestern Punjab India. Environ Geochem health. https://doi.org/10.1007/s10653-020-00518-1

61. Wen D, Zhang F, Zhang E, Wang C, Han S, Zheng Y (2013) Arsenic, fluoride and iodine in groundwater of China. J Geochem Explor 135:1-21. https://doi.org/10.1016/j.gexplo.2013.10.012
62. Rahman SM, Kippler M, Tofail F, Bölte S, Derakhshani Hamadani J, Vahter M (2017) Manganese in drinking water and cognitive abilities and behavior at 10 years of age: a prospective cohort study. Environ Health Perspect 125(5):057003. https://doi. org/10.1289/EHP631

63. Bauder TA, Waskom RM, Sutherland PL, Davis JG, Follett RH, Soltanpour PN (2011) Irrigation water quality criteria. Service in action; no. 0.506. https://mountainscholar.org/bitstream/handl e/10217/182905/AEXT_005062014.pdf?sequence=13

64. Singaraja C (2017) Relevance of water quality index for groundwater quality evaluation: Thoothukudi District, Tamil Nadu India. Appl Wat Sci 7(5):2157-2173. https://doi.org/10.1007/s1320 1-017-0594-5

65. Adimalla N, Taloor AK (2020) Hydrogeochemical investigation of groundwater quality in the hard rock terrain of South India using Geographic Information System (GIS) and groundwater quality index (GWQI) techniques. Groundw Sustain Dev 10:100288. https://doi.org/10.1016/j.gsd.2019.100288

Publisher's Note Springer Nature remains neutral with regard to jurisdictional claims in published maps and institutional affiliations. 